\title{
Geographical Variation in Morphological and Bioacoustic Traits of Pseudopaludicola mystacalis (Cope, 1887) and a Reassessment of the Taxonomic Status of Pseudopaludicola serrana Toledo, 2010 (Anura: Leptodactylidae: Leiuperinae)
}

\author{
André Pansonato, ${ }^{1}$ Jessica Rhaiza Mudrek, ${ }^{2}$ Fernanda Simioni, ${ }^{1}$ \\ Itamar Alves Martins, ${ }^{1,3}$ and Christine Strüssmann ${ }^{2,4}$ \\ ${ }^{1}$ Pós-Graduação em Biologia Animal, Universidade Estadual Paulista (UNESP), Rua Cristóvão Colombo 2265, \\ Jardim Nazareth, 15054-000 São José do Rio Preto, SP, Brazil \\ ${ }^{2}$ Pós-Graduação em Ecologia e Conservação da Biodiversidade, Instituto de Biociências, \\ Universidade Federal de Mato Grosso (UFMT), Avenida Fernando Correa da Costa 2367, Boa Esperança, \\ 78060-900 Cuiabá, MT, Brazil \\ ${ }^{3}$ Laboratório de Zoologia, Instituto Básico de Biociências, Universidade de Taubaté (UNITAU), \\ Avenida Tiradentes 500, 12030-180 Taubaté, SP, Brazil \\ ${ }^{4}$ Departamento de Ciências Básicas e Produção Animal, Faculdade de Agronomia, Medicina Veterinária e Zootecnia, \\ Universidade Federal de Mato Grosso (UFMT), Avenida Fernando Correa da Costa 2367, Boa Esperança, \\ 78060-900 Cuiabá, MT, Brazil
}

Correspondence should be addressed to André Pansonato; andre-pan@hotmail.com

Received 4 April 2014; Revised 11 June 2014; Accepted 4 July 2014; Published 12 August 2014

Academic Editor: Ariovaldo A. Giaretta

Copyright ( 2014 André Pansonato et al. This is an open access article distributed under the Creative Commons Attribution License, which permits unrestricted use, distribution, and reproduction in any medium, provided the original work is properly cited.

\begin{abstract}
Comparisons of advertisement calls of anurans can be used to determine intra- and interspecific differences or affinities. Described from midwestern Brazil, Pseudopaludicola mystacalis is widely distributed and abundant in major open Brazilian ecosystems. However, researchers frequently fail to determine the true taxonomic status of some of these populations and attribute them to unidentified or misidentified species. Herein, we employ morphological and bioacoustic data to reassess the distribution range and to evaluate intraspecific variation in P. mystacalis based on specimens from fifteen localities and seven Brazilian states. We also reassess the distribution and taxonomic status of Pseudopaludicola serrana, herein considered as a junior synonym of $P$. murundu based on morphology, bioacoustics, and molecular data.
\end{abstract}

\section{Introduction}

Advertisement calls are important for mate recognition in anurans and hence contribute to premating isolation among sympatric species [1]. Comparison of advertisement calls can be used to determine differences and affinities among different anuran species and so to determine taxonomic identity and phylogenetic relationships [2,3]. Such comparisons may be especially useful for situations in which the taxonomic identity of a species is uncertain or contested involving synonymies, redescriptions, and species resurrections. Indeed, in the absence of consistent morphological characters for interspecific distinctiveness, advertisement calls have proven to be of great help in revealing and supporting hypotheses of putative new species of Pseudopaludicola [4-9].

Described from midwestern Brazil (Chapada dos Guimarães, Mato Grosso), Pseudopaludicola mystacalis is widely distributed and abundant in open environments along 
TABLE 1: Measurements ( $\mathrm{mm}$ ) of specimens of Pseudopaludicola mystacalis from localities in four Brazilian states. Values are presented as mean \pm standard deviation (minimum-maximum). $N$ = number of specimens analyzed.

\begin{tabular}{|c|c|c|c|c|c|c|c|}
\hline & \multicolumn{2}{|c|}{ Mato Grosso } & \multicolumn{2}{|c|}{ São Paulo } & \multicolumn{2}{|c|}{ Goiás } & \multirow{2}{*}{$\begin{array}{c}\text { Pará } \\
\text { Males } \\
(N=14)\end{array}$} \\
\hline & $\begin{array}{c}\text { Males } \\
(N=53)\end{array}$ & $\begin{array}{l}\text { Females } \\
(N=20)\end{array}$ & $\begin{array}{c}\text { Males } \\
(N=14)\end{array}$ & $\begin{array}{l}\text { Females } \\
(N=7)\end{array}$ & $\begin{array}{c}\text { Males } \\
(N=20)\end{array}$ & $\begin{array}{l}\text { Females } \\
(N=6)\end{array}$ & \\
\hline \multirow{2}{*}{ SVL } & $13.9 \pm 1.3$ & $16.3 \pm 0.9$ & $13.9 \pm 0.5$ & $15.3 \pm 0.7$ & $14.1 \pm 0.1$ & $15.9 \pm 0.9$ & $15.4 \pm 0.8$ \\
\hline & $(10.9-16.3)$ & $(14.3-18.1)$ & $(13-14.9)$ & $(14.3-16)$ & $(11.7-16.5)$ & $(14.6-17)$ & $(14.6-16.6)$ \\
\hline \multirow{2}{*}{ HL } & $5.4 \pm 0.4$ & $6.2 \pm 0.5$ & $5.4 \pm 0.3$ & $5.5 \pm 0.3$ & $5.3 \pm 0.4$ & $5.8 \pm 0.5$ & $5.6 \pm 0.2$ \\
\hline & $(4.4-6.5)$ & $(5.2-7.5)$ & $(4.6-5.9)$ & $(5.1-6.0)$ & $(4.7-6.1)$ & $(5.0-6.3)$ & $(5.3-5.9)$ \\
\hline \multirow{2}{*}{ HW } & $4.8 \pm 0.5$ & $5.9 \pm 0.6$ & $4.8 \pm 0.2$ & $5.1 \pm 0.4$ & $4.9 \pm 0.5$ & $5.5 \pm 0.4$ & $4.8 \pm 0.3$ \\
\hline & $(3.7-6.7)$ & $(5.0-6.8)$ & $(4.3-5.1)$ & $(4.6-5.8)$ & $(4.3-6.4)$ & $(4.9-5.9)$ & $(4.5-5.3)$ \\
\hline \multirow{2}{*}{ IOD } & $1.1 \pm 0.2$ & $1.4 \pm 0.2$ & $1.2 \pm 0.1$ & $1.3 \pm 0.1$ & $1.2 \pm 0.2$ & $1.4 \pm 0.2$ & $1.4 \pm 0.2$ \\
\hline & $(0.7-1.6)$ & $(0.8-1.7)$ & $(1.0-1.4)$ & $(1.1-1.4)$ & $(1.0-1.7)$ & $(1.2-1.8)$ & $(1.1-1.5)$ \\
\hline \multirow{2}{*}{$\mathrm{ED}$} & $1.6 \pm 0.2$ & $1.7 \pm 0.2$ & $1.4 \pm 0.1$ & $1.5 \pm 0.2$ & $1.5 \pm 0.1$ & $1.6 \pm 0.1$ & $1.7 \pm 0.08$ \\
\hline & $(1.0-1.9)$ & $(1.3-2.3)$ & $(1.1-1.7)$ & $(1.3-1.9)$ & $(1.2-1.7)$ & $(1.4-1.8)$ & $(1.6-1.8)$ \\
\hline \multirow{2}{*}{ END } & $1.2 \pm 0.2$ & $1.4 \pm 0.2$ & $1.1 \pm 0.07$ & $1.3 \pm 0.2$ & $1.2 \pm 0.1$ & $1.3 \pm 0.1$ & $1.2 \pm 0.1$ \\
\hline & $(0.7-1.8)$ & $(1.1-2.1)$ & $(1.0-1.2)$ & $(1.1-1.8)$ & $(0.9-1.5)$ & $(1.1-1.4)$ & $(1.1-1.4)$ \\
\hline \multirow{2}{*}{ IND } & $1.2 \pm 0.2$ & $1.5 \pm 0.2$ & $1.3 \pm 0.1$ & $1.4 \pm 0.09$ & $1.4 \pm 0.1$ & $1.5 \pm 0.2$ & $1.3 \pm 0.09$ \\
\hline & $(0.8-1.7)$ & $(1.0-1.9)$ & $(1.1-1.5)$ & $(1.3-1.5)$ & $(1.1-1.7)$ & $(1.2-1.7)$ & $(1.2-1.4)$ \\
\hline \multirow{2}{*}{ HAL } & $3.7 \pm 0.3$ & $4.4 \pm 0.7$ & $3.9 \pm 0.2$ & $4.2 \pm 0.4$ & $3.8 \pm 0.2$ & $4.1 \pm 0.3$ & $3.9 \pm 0.2$ \\
\hline & $(3.1-4.4)$ & $(3.2-6.3)$ & $(3.5-4.3)$ & $(3.8-4.8)$ & $(3.4-4.4)$ & $(3.8-4.5)$ & $(3.6-4.1)$ \\
\hline \multirow{2}{*}{ THL } & $6.3 \pm 0.5$ & $7.7 \pm 0.9$ & $6.2 \pm 0.3$ & $6.6 \pm 0.6$ & $6.5 \pm 0.5$ & $7.4 \pm 0.2$ & $6.8 \pm 0.2$ \\
\hline & $(5.1-7.3)$ & $(6.4-9.4)$ & $(5.6-6.9)$ & $(5.3-7.1)$ & $(5.6-7.3)$ & $(7.1-7.7)$ & $(6.6-7.2)$ \\
\hline \multirow{2}{*}{$\mathrm{TL}$} & $6.9 \pm 0.5$ & $8.3 \pm 0.9$ & $7 \pm 0.3$ & $7.5 \pm 0.3$ & $7.1 \pm 0.4$ & $7.8 \pm 0.2$ & $7.4 \pm 0.2$ \\
\hline & $(5.9-8.2)$ & $(7.2-9.8)$ & $(6.7-7.6)$ & $(7.1-7.8)$ & $(6.4-8.0)$ & $(7.5-8.1)$ & $(7.2-7.6)$ \\
\hline \multirow{2}{*}{ TAL } & $3.9 \pm 0.4$ & $4.5 \pm 0.6$ & $3.9 \pm 0.2$ & $4.3 \pm 0.3$ & $3.9 \pm 0.3$ & $4.3 \pm 0.3$ & $3.9 \pm 0.3$ \\
\hline & $(3.1-4.6)$ & $(3.1-5.2)$ & $(3.5-4.5)$ & $(3.9-4.6)$ & $(3.2-4.5)$ & $(4.0-4.8)$ & $(3.4-4.2)$ \\
\hline \multirow{2}{*}{ FL } & $7.7 \pm 0.5$ & $9.2 \pm 0.8$ & $7.9 \pm 0.3$ & $8.4 \pm 0.5$ & $7.7 \pm 0.4$ & $8.5 \pm 0.6$ & $8.1 \pm 0.5$ \\
\hline & $(6.3-9.2)$ & $(7.9-10.6)$ & $(7.3-8.4)$ & $(7.6-8.9)$ & $(6.9-8.2)$ & $(7.8-9.2)$ & $(7.6-8.8)$ \\
\hline
\end{tabular}

South American "diagonal of open formations" [8]. However, some populations along the species' range are not recognized as belonging to this taxon, being rather attributed to other taxonomic entities, such as Pseudopaludicola aff. falcipes, Pseudopaludicola aff. mystacalis, and Pseudopaludicola sp. [10-14]. Therefore, an integrative taxonomic revision is needed to clarify the distribution range and variation in this species [9].

In spite of great morphological similarity among most of the 18 species of Pseudopaludicola currently recognized, three of them are readily distinguished from the others by having longer hindlimbs [4-6, 8, 9]: Pseudopaludicola saltica (Cope, 1887), Pseudopaludicola murundu Toledo, Siqueira, Duarte, Veiga-Menoncello, Recco-Pimentel, and Haddad, 2010, and Pseudopaludicola serrana Toledo, 2010. Advertisement calls of all three species are similarly composed of series of notes with nonconcatenated pulses $[8,15-17]$ and they all share $2 n=$ 22 chromosomes $[16,18]$ comprising a monophyletic clade [19]. However, the results of a recent molecular phylogenetic analysis suggested that $P$. serrana is a junior synonym of $P$. murundu [19].
Objectives of the present article are (1) to provide and to discuss the intraspecific variation in morphological and bioacoustic traits of $P$. mystacalis along its distribution range in Brazil; (2) to reassess the taxonomic status of P. serrana, based on the reinterpretation of the literature data and on the examination of new materials (specimens and calls), freshly obtained at the type-locality and/or its vicinities of $P$. serrana and related species.

\section{Material and Methods}

Examined specimens of $P$. mystacalis, $P$. murundu, $P$. saltica, and $P$. serrana (Appendices A and B) are deposited in the following collections: "Coleção Zoológica de Vertebrados, Universidade Federal de Mato Grosso" (UFMT, Cuiabá, Mato Grosso, Brazil), "Coleção Herpetológica da Universidade Federal do Ceará” (UFC, Fortaleza, Ceará), "Fonoteca Neotropical Jacques Vielliard” (FNJV, Campinas, São Paulo), and "Museu de Ciências Naturais" (MCNAM, Belo Horizonte, Minas Gerais). Material deposited at UFMT was 
TABle 2: Measurements $(\mathrm{mm})$ of the topotypes of Pseudopaludicola serrana and P. murundu. Values are presented as mean \pm standard deviation (minimum-maximum). Additional localities (state of Minas Gerais, municipalities of Itabirito, Lavras Novas, Mariana, Ouro Branco, São João Del Rei, and Botumirim). $N$ = number of specimens analyzed.

\begin{tabular}{|c|c|c|c|c|c|c|}
\hline & & Pseud & a serrana & & Pseud & turundu \\
\hline & & & Addit & alities & & \\
\hline & $\begin{array}{c}\text { Males } \\
(N=5)\end{array}$ & $\begin{array}{l}\text { Females } \\
(N=1)\end{array}$ & $\begin{array}{c}\text { Males } \\
(N=16)\end{array}$ & $\begin{array}{l}\text { Females } \\
(N=5)\end{array}$ & $\begin{array}{c}\text { Males } \\
(N=5)\end{array}$ & $\begin{array}{c}\text { Females } \\
(N=1)\end{array}$ \\
\hline SVL & $16.3 \pm 1.2$ & 17.7 & $15.2 \pm 0.9$ & $17.1 \pm 1.2$ & $15.9 \pm 0.8$ & 17.3 \\
\hline & $(14.6-17.5)$ & & $(12.6-16.7)$ & $(15.9-18.5)$ & $(15.2-16.9)$ & \\
\hline HL & $6.5 \pm 0.5$ & 6.8 & $6.0 \pm 0.4$ & $6.7 \pm 0.3$ & $6.1 \pm 0.4$ & 6.8 \\
\hline & $(6.2-7.3)$ & & $(4.8-6.9)$ & $(6.3-7.1)$ & $(5.6-6.7)$ & \\
\hline HW & $6.0 \pm 0.2$ & 6.6 & $5.5 \pm 0.4$ & $6.3 \pm 0.3$ & $5.5 \pm 0.2$ & 5.9 \\
\hline & $(5.7-6.3)$ & & $(4.7-6.1)$ & $(5.9-6.7)$ & $(5.3-5.8)$ & \\
\hline IOD & $1.4 \pm 0.1$ & 1.8 & $1.4 \pm 0.1$ & $1.6 \pm 0.07$ & $1.4 \pm 0.0 .8$ & 1.5 \\
\hline & $(1.3-1.6)$ & & $(1.2-1.6)$ & $(1.5-1.7)$ & $(1.3-1.5)$ & \\
\hline ED & $1.6 \pm 0.07$ & 1.7 & $1.5 \pm 0.1$ & $1.6 \pm 0.09$ & $1.6 \pm 0.2$ & 1.9 \\
\hline & $(1.5-1.7)$ & & $(1.3-1.7)$ & $(1.5-1.7)$ & $(1.4-1.8)$ & \\
\hline END & $1.6 \pm 0.09$ & 1.6 & $1.5 \pm 0.1$ & $1.5 \pm 0.08$ & $1.5 \pm 0.08$ & 1.6 \\
\hline Liv & $(1.5-1.7)$ & & $(1.3-1.7)$ & $(1.4-1.6)$ & $(1.4-1.6)$ & \\
\hline IND & $1.5 \pm 0.1$ & 1.8 & $1.4 \pm 0.1$ & $1.6 \pm 0.08$ & $1.5 \pm 0.09$ & 1.6 \\
\hline $11 \mathrm{VD}$ & $(1.3-1.7)$ & & $(1.2-1.7)$ & $(1.5-1.7)$ & $(1.4-1.7)$ & \\
\hline HAL & $4.4 \pm 0.1$ & 4.9 & $4.1 \pm 0.4$ & $4.5 \pm 0.1$ & $4.3 \pm 0.2$ & 4.9 \\
\hline & $(4.3-4.6)$ & & $(3.4-4.6)$ & $(4.3-4.7)$ & $(4.2-4.6)$ & \\
\hline THL & $9.0 \pm 0.3$ & 10.2 & $8.5 \pm 0.7$ & $9.4 \pm 0.5$ & $8.9 \pm 0.3$ & 9.5 \\
\hline $111 \mathrm{~L}$ & $(8.5-9.3)$ & & $(6.8-9.4)$ & $(8.7-10.1)$ & $(8.6-9.3)$ & \\
\hline TL & $10.9 \pm 0.3$ & 12.7 & $10.7 \pm 0.7$ & $11.8 \pm 0.5$ & $11.2 \pm 0.3$ & 12.3 \\
\hline & $(10.6-11.3)$ & & $(8.9-11.5)$ & $(10.9-12.2)$ & $(10.8-11.6)$ & \\
\hline TAI & $5.3 \pm 0.2$ & 5.8 & $5.1 \pm 0.4$ & $5.7 \pm 0.4$ & $5.4 \pm 0.07$ & 6.3 \\
\hline $17 \mathrm{H}$ & $(5.1-5.7)$ & & $(4.2-5.5)$ & $(5.0-6.1)$ & $(5.4-5.6)$ & \\
\hline FI & $9.8 \pm 0.3$ & 11.1 & $9.3 \pm 0.8$ & $10.2 \pm 0.5$ & $10.6 \pm 0.4$ & 11.4 \\
\hline $1 \mathrm{~L}$ & $(9.5-10.3)$ & & $(7.4-10.4)$ & $(9.5-10.6)$ & $(9.9-10.9)$ & \\
\hline
\end{tabular}

collected with permission of the "Instituto Chico Mendes de Conservação da Biodiversidade" (ICMBIO 27231-1).

Since the available diagnoses for $P$. serrana and $P$. murundu do not allow clearly distinguishing specimens from these two species, new material from additional localities was putatively associated with each of them based solely on the positioning of collecting and/or recording sites: populations from easternmost localities in Minas Gerais were considered to represent $P$. serrana and populations from westernmost localities in Minas Gerais (and those from the state of São Paulo) were considered to represent P. murundu.

The measurements of 218 adult specimens (Tables 1 and 2) of $P$. murundu (6 males; 1 female), P. mystacalis (101 males; 37 females), $P$. saltica (39 males; 3 females; original data in Pansonato et al. [8]), and P. serrana (22 males; 6 females) were taken with a digital caliper to the nearest $0.1 \mathrm{~mm}$. Measurements for hand length (HAL), tibia length (TL), tarsus length (TAL), and foot length (FL) followed Heyer et al. [20]. Measurements for snout-vent length (SVL), head length (HL), head width (HW), interorbital distance (IOD), eye diameter (ED), eye-nostril distance (END), internarial distance (IND), and thigh length (THL) followed Duellman [21].

Vocalizations of specimens of $P$. murundu, $P$. mystacalis, $P$. saltica, and $P$. serrana were recorded by André Pansonato with a professional digital recorder Marantz PMD 660 equipped with a Yoga EM-9600 external directional microphone. Digital recordings were sampled at $44.1 \mathrm{kHz}$ sampling rate and 16 bit resolution and saved in uncompressed wave files. Spectrograms were edited using Raven Pro 1.3 software with the following configuration: for P. mystacalis, brightness 75\%; contrast $80 \%$; DFT size 512 samples; $3 \mathrm{~dB}$ filter bandwidth $112 \mathrm{~Hz}$; time grid overlap 50\%; for P. murundu, $P$. saltica, and $P$. serrana, brightness 70\%; contrast $80 \%$; DFT size 512 samples; $3 \mathrm{~dB}$ filter bandwidth $124 \mathrm{~Hz}$; time grid overlap 50\%.

We analyzed 1894 notes (Tables 3 and 4): 503 from $P$. murundu, 444 notes from $P$. mystacalis, 577 from $P$. saltica, and 370 from $P$. serrana. The following temporal variables were measured from the waveform: number of pulses per note; note and pulse duration (ms); internote and interpulse interval (ms). Note that repetition rate was calculated in 
TABLE 3: Measurements of bioacoustic variables of the advertisement calls of specimens of Pseudopaludicola mystacalis from 12 localities in seven Brazilian states (CE: Ceará; GO: Goiás; MA: Maranhão; MT: Mato Grosso; PA: Pará; PI: Piauí; SP: São Paulo). Values are presented as mean \pm standard deviation (minimum-maximum). $N$ : number of notes analyzed.

\begin{tabular}{|c|c|c|c|c|c|c|c|}
\hline Locality-State & Air temp & $\begin{array}{c}\text { Note } \\
\text { duration }(\mathrm{ms})\end{array}$ & $\begin{array}{c}\text { Internote } \\
\text { interval (ms) }\end{array}$ & $\begin{array}{l}\text { Pulses per } \\
\text { note }\end{array}$ & $\begin{array}{c}\text { Pulse } \\
\text { duration (ms) }\end{array}$ & $\begin{array}{c}\text { Dominant } \\
\text { frequency }(\mathrm{Hz})\end{array}$ & $\begin{array}{l}\text { Notes/min } \\
\text { (mean) }\end{array}$ \\
\hline Poconé-MT $(N=30)$ & $25.6^{\circ} \mathrm{C}$ & $\begin{array}{c}40 \pm 5 \\
(30-50)\end{array}$ & $\begin{array}{c}80 \pm 10 \\
(60-100)\end{array}$ & $\begin{array}{c}16 \pm 1.2 \\
(14-18)\end{array}$ & $\begin{array}{c}2 \pm 0.3 \\
(1-2)\end{array}$ & $\begin{array}{l}4684.2 \pm 115.7 \\
(4522-4909.6)\end{array}$ & 511.1 \\
\hline N.S. Livramento-MT $(N=25)$ & $25.2^{\circ} \mathrm{C}$ & $\begin{array}{c}40 \pm 4 \\
(40-50)\end{array}$ & $\begin{array}{c}70 \pm 30 \\
(50-200)\end{array}$ & $\begin{array}{l}17 \pm 1.0 \\
(14-19)\end{array}$ & $\begin{array}{c}2 \pm 0.3 \\
(1-2)\end{array}$ & $\begin{array}{c}4811.4 \pm 56.3 \\
(4737.3-4909.6)\end{array}$ & 506.4 \\
\hline C. Guimarães-MT $(N=110)$ & $26.3^{\circ} \mathrm{C}$ & $\begin{array}{c}40 \pm 4 \\
(30-50)\end{array}$ & $\begin{array}{c}60 \pm 10 \\
(40-100)\end{array}$ & $\begin{array}{c}16 \pm 0.8 \\
(14-17)\end{array}$ & $\begin{array}{c}2 \pm 0.4 \\
(1-2)\end{array}$ & $\begin{array}{l}4962.4 \pm 181.5 \\
(4651.2-5254.1)\end{array}$ & 576.9 \\
\hline Cuiabá-MT $(N=25)$ & $26^{\circ} \mathrm{C}$ & $\begin{array}{c}50 \pm 4 \\
(30-50)\end{array}$ & $\begin{array}{c}90 \pm 10 \\
(60-100)\end{array}$ & $\begin{array}{c}14 \pm 0.8 \\
(12-16)\end{array}$ & $\begin{array}{c}2 \pm 0.4 \\
(1-3)\end{array}$ & $\begin{array}{c}4775.2 \pm 82.8 \\
(4651.2-4909.6)\end{array}$ & 443.3 \\
\hline Cuiabá-MT $(N=25)$ & $26^{\circ} \mathrm{C}$ & $\begin{array}{c}45 \pm 4 \\
(30-50)\end{array}$ & $\begin{array}{c}80 \pm 30 \\
(50-200)\end{array}$ & $\begin{array}{c}16 \pm 1.0 \\
(13-18)\end{array}$ & $\begin{array}{c}2 \pm 0.3 \\
(1-2)\end{array}$ & $\begin{array}{c}4837.2 \pm 150 \\
(4478.9-4995.7)\end{array}$ & 524.3 \\
\hline Cáceres-MT $(N=25)$ & $26^{\circ} \mathrm{C}$ & $\begin{array}{c}50 \pm 3 \\
(40-50)\end{array}$ & $\begin{array}{l}60 \pm 50 \\
(50-70)\end{array}$ & $\begin{array}{l}16 \pm 1.0 \\
(14-18)\end{array}$ & $\begin{array}{c}2 \pm 0.3 \\
(1-2)\end{array}$ & $\begin{array}{c}4901 \pm 51.2 \\
(4737.3-4995.7)\end{array}$ & 538.9 \\
\hline Balsas-MA $(N=30)$ & $26.5^{\circ} \mathrm{C}$ & $\begin{array}{l}40 \pm 2 \\
(37-45)\end{array}$ & $\begin{array}{c}80 \pm 5 \\
(70-90)\end{array}$ & $\begin{array}{c}16 \pm 1.0 \\
(14-18)\end{array}$ & $\begin{array}{c}2 \pm 0.4 \\
(1-2)\end{array}$ & $\begin{array}{c}5076.09 \pm 205.68 \\
(4780.4-5340.2)\end{array}$ & 513.7 \\
\hline Icém-SP $(N=28)$ & $23^{\circ} \mathrm{C}$ & $\begin{array}{c}50 \pm 5 \\
(50-60)\end{array}$ & $\begin{array}{c}110 \pm 7 \\
(100-150)\end{array}$ & $\begin{array}{l}17 \pm 1.7 \\
(14-20)\end{array}$ & $\begin{array}{c}2 \pm 0.4 \\
(1-2)\end{array}$ & $\begin{array}{c}4872.2 \pm 79.9 \\
(4737.3-4974.2)\end{array}$ & 363.3 \\
\hline Itapipoca-CE $(N=30)$ & - & $\begin{array}{c}50 \pm 3 \\
(40-50)\end{array}$ & $\begin{array}{c}90 \pm 10 \\
(70-130)\end{array}$ & $\begin{array}{c}16 \pm 1.2 \\
(14-18)\end{array}$ & $\begin{array}{c}2 \pm 0.4 \\
(1-2)\end{array}$ & $\begin{array}{l}5128.2 \pm 98.1 \\
(4780.4-5211)\end{array}$ & 420.7 \\
\hline Taíba-CE $(N=30)$ & - & $\begin{array}{c}40 \pm 2 \\
(40-50)\end{array}$ & $\begin{array}{c}70 \pm 2 \\
(60-70)\end{array}$ & $\begin{array}{c}16 \pm 1.1 \\
(13-18)\end{array}$ & $\begin{array}{r}2 \pm 0.5 \\
(1-3)\end{array}$ & $\begin{array}{c}4795.2 \pm 85.2 \\
(4694.2-4952.6)\end{array}$ & 535.3 \\
\hline Brejo do Buriti-PI $(N=30)$ & $27^{\circ} \mathrm{C}$ & $\begin{array}{c}50 \pm 1 \\
(45-50)\end{array}$ & $\begin{array}{c}90 \pm 20 \\
(60-140)\end{array}$ & $\begin{array}{l}19 \pm 0.6 \\
(18-20)\end{array}$ & 2 & $\begin{array}{l}4860.75 \pm 31.48 \\
(4823.4-4909.6)\end{array}$ & 429.6 \\
\hline Primavera-PA $(N=30)$ & $25.5^{\circ} \mathrm{C}$ & $\begin{array}{c}50 \pm 2 \\
(40-50)\end{array}$ & $\begin{array}{c}80 \pm 5 \\
(70-100)\end{array}$ & $\begin{array}{c}18 \pm 1.2 \\
(16-20)\end{array}$ & $\begin{array}{r}2 \pm 0.5 \\
(1-2)\end{array}$ & $\begin{array}{c}5040.6 \pm 45.6 \\
(4921.9-5109.4)\end{array}$ & 463.7 \\
\hline Uruaçu-GO $(N=26)$ & $24.5^{\circ} \mathrm{C}$ & $\begin{array}{c}50 \pm 2 \\
(40-50)\end{array}$ & $\begin{array}{c}60 \pm 5 \\
(50-80)\end{array}$ & $\begin{array}{l}16 \pm 1.2 \\
(14-18)\end{array}$ & $\begin{array}{c}2 \pm 0.5 \\
(1-2)\end{array}$ & $\begin{array}{c}4633.4 \pm 86.6 \\
(4500-4968.8)\end{array}$ & 543.5 \\
\hline Mean \pm SD & & $\begin{array}{c}50 \pm 4 \\
(30-60)\end{array}$ & $\begin{array}{c}80 \pm 10 \\
(40-200)\end{array}$ & $\begin{array}{l}16 \pm 1.7 \\
(12-20)\end{array}$ & $\begin{array}{c}2 \pm 0.4 \\
(1-3)\end{array}$ & $\begin{array}{c}4887.4 \pm 149.5 \\
(4478.9-5340.2)\end{array}$ & $\begin{array}{c}490.1 \pm 61.1 \\
(363.3-576.9)\end{array}$ \\
\hline
\end{tabular}

notes per minute. Dominant frequency (note peak frequency; $\mathrm{Hz}$ ) was obtained from the spectrogram. Terminology for bioacoustic variables follows Magalhães et al. [7], Pansonato et al. [8], and Heyer et al. [20]. Vocalizations are archived in the "Banco de Registros Bioacústicos" and housed at the "Laboratório de Herpetologia do Instituto de Biociências da Universidade Federal de Mato Grosso" (LH, Cuiabá, Mato Grosso).

Discriminant function analyses (DFA) were conducted in order to evidence the set of morphometric and bioacoustic variables that mostly distinguish between the species of Pseudopaludicola compared herein. DFA were performed on correlation matrices from 12 log-transformed morphometric and six bioacoustic variables using $\mathrm{R}$ platform version 3.0.1 [22]. Bioacoustic comparisons through the DFA were performed using mean individual values.

\section{Results}

3.1. Geographical Variation in Pseudopaludicola mystacalis (Cope, 1887). Based on morphology and bioacoustics, Pseudopaludicola mystacalis was positively identified in fifteen localities (Figure 1) from seven Brazilian states: Ceará, Goiás,
Maranhão, Mato Grosso, Pará, Piauí, and São Paulo. The advertisement calls of Pseudopaludicola mystacalis along its distribution range in Brazil (Figures 1 and 2) consisted of series composed of 9-229 notes with $16 \pm 1.7$ (12-20) concatenated pulses (i.e., no interpulse intervals). Mean note repetition rate was $490.1 \pm 61.1$ notes/min (363.3-576.9); mean duration of each note was $50 \pm 4 \mathrm{~ms}$ (30-60); average internote interval varied from $80 \pm 10 \mathrm{~ms}(40-200)$. Mean pulse duration was $2 \pm 0.4 \mathrm{~ms}(1-3)$. Frequency ranged from 2686.2 Hz to $7343.3 \mathrm{~Hz}$ and dominant frequency ranged from 4478.9 to $5340.2 \mathrm{~Hz}$ (Table 3 ).

Discriminant function analysis (DFA) with our data on $P$. mystacalis did not group localities, neither regarding morphometric characters (males and females) nor regarding bioacoustic variables. The first function (DF1) of DFA with morphometric data explained $63 \%$ of the variation among males of different populations (Figure 3(a)) and higher loadings corresponded to thigh length (10.5), hand length (9.8), and foot length (8.4). The DF1 explained $85 \%$ of the variation among females (Figure 3(b)) and higher loadings corresponded to hand length (12.3), foot length (10.7), and snout-vent length (8.8). The DF1 of DFA with bioacoustic variables explained $79 \%$ of the total variation in our sample 


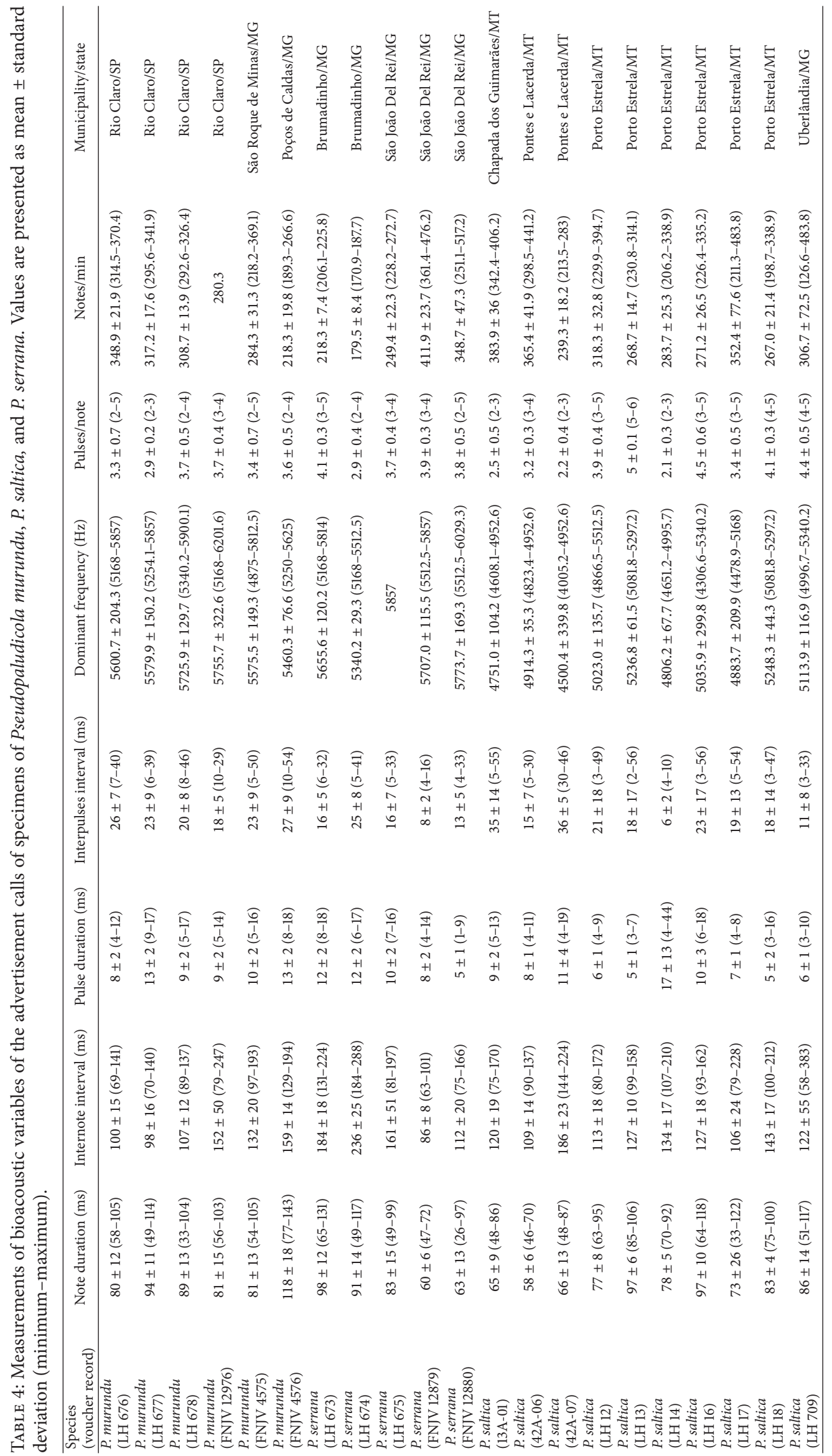




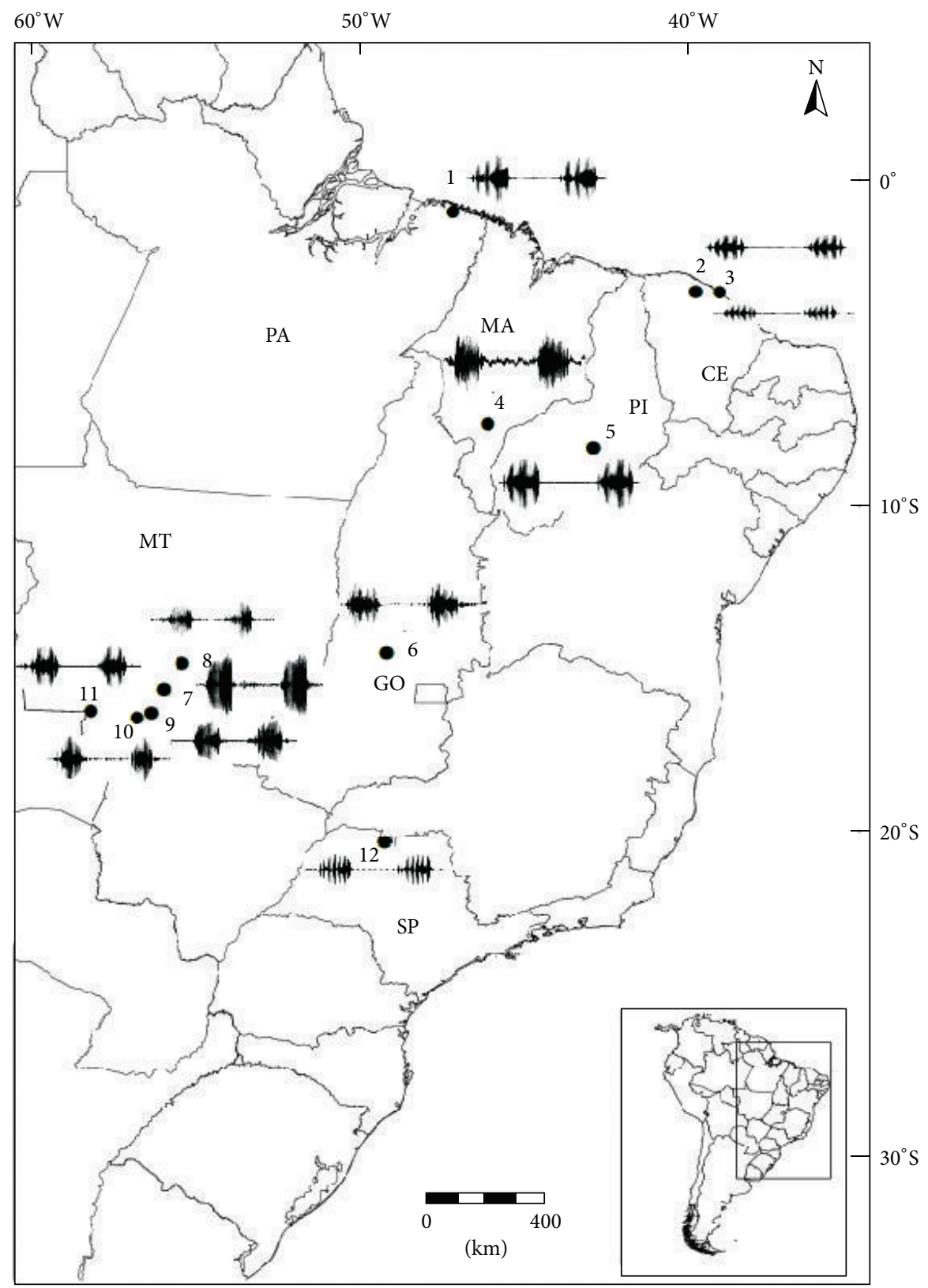

Figure 1: Geographical variation in the advertisement calls (oscillograms) of Pseudopaludicola mystacalis from twelve localities in seven Brazilian states: Pará (PA): Primavera (1); Ceará (CE): Itapipoca (2); Taíba (3); Maranhão (MA): Balsas (4); Piauí (PI): Brejo do Piauí (5); Goiás (GO): Uruaçu (6); Mato Grosso (MT): Cuiabá (7); Chapada dos Guimarães (8); Nossa Senhora do Livramento (9); Poconé (10); Cáceres (11); São Paulo (SP): Icém (12). Total time of each oscillogram corresponds to $0.2 \mathrm{~s}$.

(Figure 3(c)) and higher loadings corresponded to note rate (38.5), internote interval (29.5), and note duration (22.1). No distinct groups were formed along the first function axis of the DFA.

3.2. Taxonomic Status of Pseudopaludicola serrana Toledo, 2010. Advertisement calls of Pseudopaludicola serrana recorded at the type-locality (Brumadinho, Minas Gerais) and nearly $120 \mathrm{~km}$ southwestwards at Serra do Lenheiro, Minas Gerais were similar to those of topotypes of $P$. murundu and distinct from topotypes of $P$. saltica, both in spectral and temporal parameters (Figures 4 and 5). The intraspecific variation in bioacoustic parameters of $P$. murundu and P. serrana, presented below, is based on calls from topotypical specimens and on calls recorded in additional localities listed in Appendix B.

Advertisement calls of $P$. serrana were composed of series of pulsed notes with nonconcatenated pulses. Each note consisted of 3.6 \pm 0.6 (range 2-5) pulses. Mean note duration was $82 \pm 58 \mathrm{~ms}(26-131)$ emitted, on average, at intervals of $167 \pm$ $58 \mathrm{~ms}$ (63-288). Mean duration of each pulse was $9 \pm 3 \mathrm{~ms}$ 


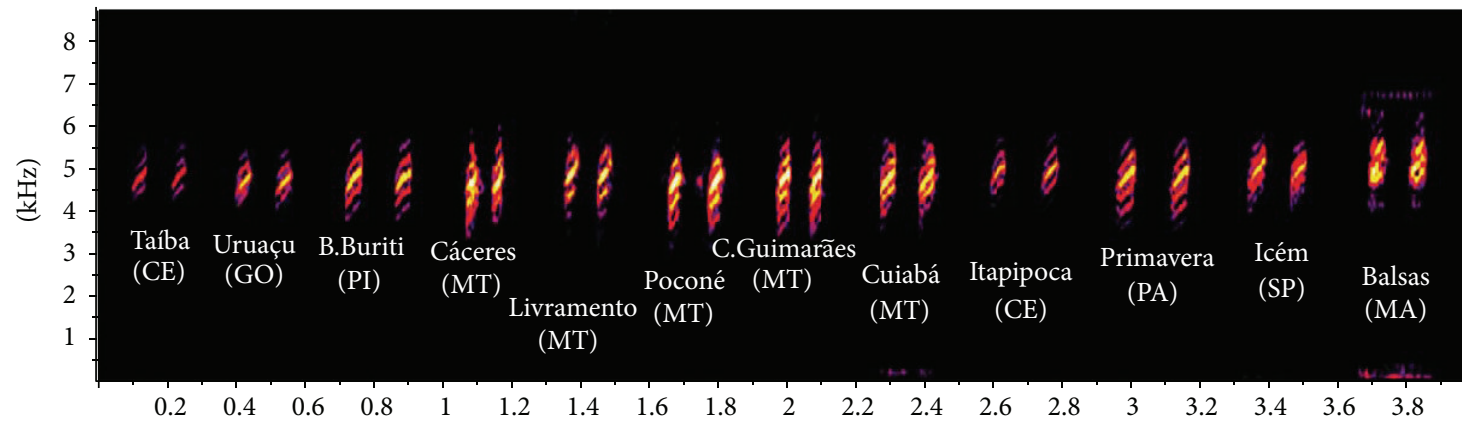

(s)

FIGURE 2: Spectrograms (DFT size $=512$ samples) of the advertisement calls of Pseudopaludicola mystacalis from twelve localities (two notes for each locality) in seven Brazilian states (CE: Ceará; GO: Goiás; MA: Maranhão; MT: Mato Grosso; PA: Pará; PI: Piauí; SP: São Paulo).

(2-18). Interpulse intervals were $16 \pm 7 \mathrm{~ms}$ long (4-41). Mean frequency ranged from $4019.6 \pm 453 \mathrm{~Hz}$ to $7098.6 \pm 312 \mathrm{~Hz}$ and mean dominant frequency was $5625.1 \pm 212 \mathrm{~Hz}(5168-$ 6029.3). Advertisement calls of $P$. murund $u$ were composed of series of pulsed notes with nonconcatenated pulses. Each note consisted of $3.4 \pm 0.6$ (range $2-5$ ) pulses. Mean note duration was $92 \pm 18 \mathrm{~ms}(33-143)$ emitted, on average, at intervals of $121 \pm 30 \mathrm{~ms}(69-247)$. Mean duration of each pulse was $10 \pm$ $3 \mathrm{~ms}$ (4-18). Interpulse intervals were $24 \pm 8 \mathrm{~ms}$ (5-54). Mean frequency ranged from $3628.5 \pm 513 \mathrm{~Hz}$ to $7330.1 \pm 355 \mathrm{~Hz}$ and mean dominant frequency was $5590.1 \pm 176 \mathrm{~Hz}$ (4875$6201.6 \mathrm{~Hz})$.

A discriminant function analysis (DFA) with morphometric data revealed that $P$. serrana and $P$. murundu overlapped along the first function (DF1) of DFA, which explained $98 \%$ of the total variation (Figure 6(a)). While the DFA did not separate $P$. serrana from $P$. murundu, both were separated from a third species (Pseudopaludicola saltica) whose individuals also have long hindlimbs. Higher loadings corresponded to eye diameter (12.1), tarsus length (7.5), and tibia length (4.6). DFA from bioacoustic data also separated Pseudopaludicola saltica from $P$. murundu and $P$. serrana (Figure $6(\mathrm{~b})$ ). The first function (DF1) of DFA explained 99\% of the total variation and higher loadings corresponded to dominant frequency (64.1) and number of pulses per note (6.1).

DFA of morphometric measurements using all specimens assigned $100 \%$ of the individuals of Pseudopaludicola saltica, $86 \%$ of the individuals of $P$. serrana, and only $16 \%$ of the individuals of $P$. murundu to the correct species (Table 5). DFA of bioacoustic variables using all recorded males correctly assigned $89 \%$ of the specimens of $P$. saltica, $83 \%$ of the specimens of $P$. murund $u$, and $40 \%$ of $P$. serrana (Table 5). In contrast, DFA with both morphometric and bioacoustic data using specimens of $P$. saltica and a mixed sample of specimens attributable to either P. murundu or P. serrana assigned $100 \%$ of these latter to a single taxon.

The overall similarity in morphology and general structure of the call of $P$. murundu and P. serrana, evidenced by the results of DFA with 12 morphometric and six bioacoustic variables, strongly support the rejection of the specific status of Pseudopaludicola serrana, here considered to be a junior synonym of Pseudopaludicola murundu. Geographical distribution of Pseudopaludicola murundu, as presently recognized, is not anymore restricted to its type-locality [16] but includes instead twelve distinct localities in southeastern Brazil in the states of Minas Gerais and São Paulo (Figure 7).

\section{Discussion}

4.1. Geographical Variation in Pseudopaludicola mystacalis (Cope, 1887). Among the 18 valid species of Pseudopaludicola, P. mystacalis is currently the one with the most widespread distribution range. Extent of occurrence in Brazil is nearly two million square kilometers encompassing areas in three different ecoregions along all the "diagonal of open formations" from South America [23]: Caatinga, Cerrado, and Pantanal. It is also found in areas of Chaco in Argentina [24] and Paraguay [25]. Although plausible, the occurrence in Bolivian Chaco was based on material that morphologically and bioacoustically would correspond to P. ameghini $[12,26]$. Habitats where individuals of this species were found include "restinga" [10, present study], "campo sujo" in elevated plateaus of the Cerrado Domain, and seasonally flooded fields in the Pantanal lowlands [8].

Advertisement calls of Pseudopaludicola mystacalis from different Brazilian localities are composed of series of notes with concatenated pulses. Maximum variation in dominant frequency of the calls of all specimens analyzed is $861.3 \mathrm{~Hz}$ (from $4478.9 \mathrm{~Hz}$, in Cuiabá, Mato Grosso, to $5340.2 \mathrm{~Hz}$, in Balsas, Maranhão; Table 3) without any evident latitudinal or longitudinal trend. Dominant frequency in the most distant known locations (Primavera, state of Pará, and Icém, state of São Paulo) varied by $372.1 \mathrm{~Hz}$. Considering subsets of populations from Brazilian Northeast (states of Ceará, Maranhão, and Piauí) and from Brazilian Midwest (states of Mato Grosso and Goiás), maximum interpopulational variation in dominant frequency is $646 \mathrm{~Hz}$ and $775.2 \mathrm{~Hz}$, respectively. Maximum intrapopulational variation in dominant frequency, evaluated for four localities in the lower portion of the species' range (Cáceres, Cuiabá, Nossa Senhora do Livramento, and Poconé, state of Mato Grosso), is $516.8 \mathrm{~Hz}$ in Cuiabá (see Table 3 and [8]). 


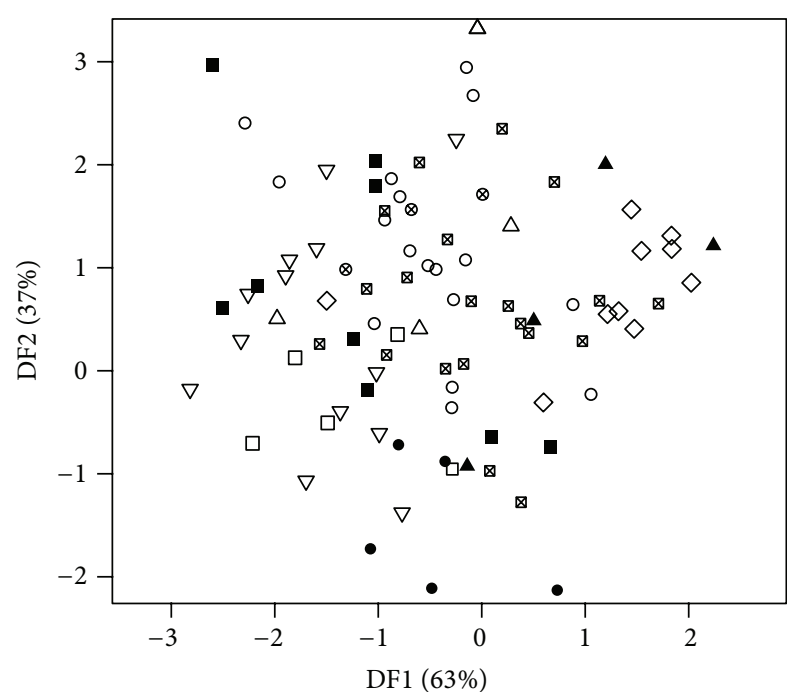

(a)

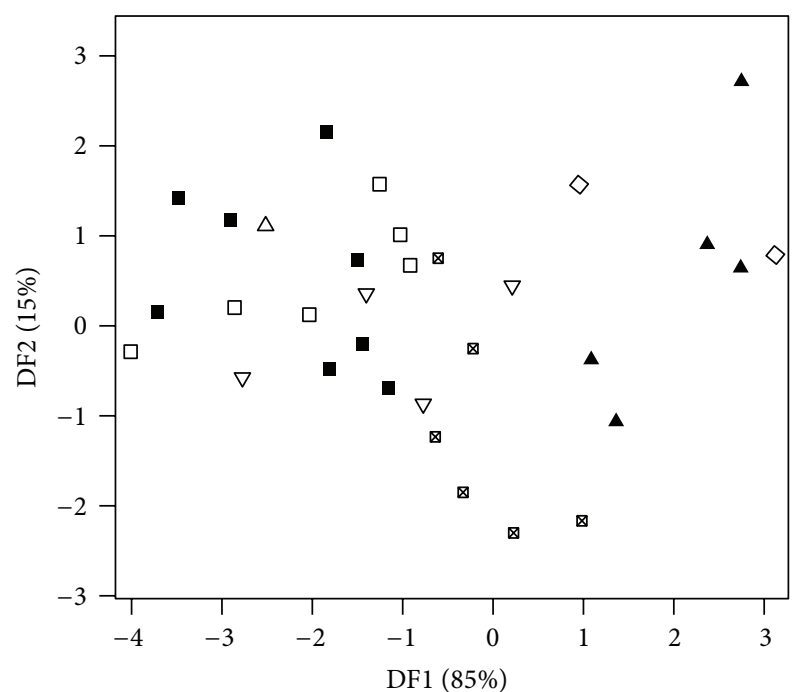

(b)

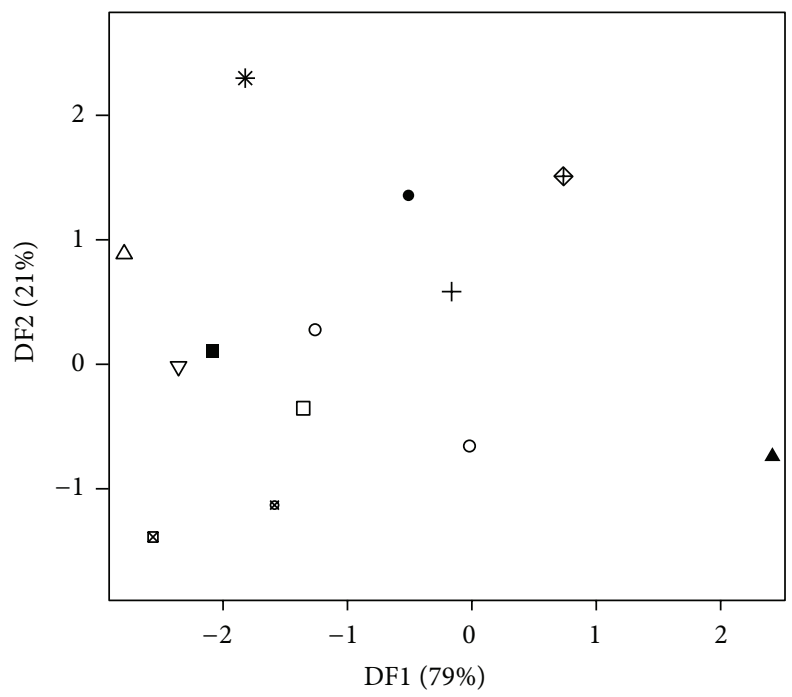
$\Delta$ Chapada dos Guimarães-MT
- Cuiabá-MT
$\square$ N.S. Livramento-MT
$\nabla$ Porto Estrela-MT
- Cáceres-MT
$\otimes$ Barra do Garças-MT
$\nabla$ Poconé-MT
$\bowtie$ Uruaçu-GO

$\diamond$ Alto Alegre-SP

A Icém-SP

- Primavera-PA

$\leftrightarrow$ Itapipoca-CE

$\otimes$ Taíba-CE

* Balsas-MA

+ Brejo do Piauí-PI

(c)

FiguRE 3: Scatterplots, on the two discriminant axes (DF1 and DF2), of scores of 12 morphometric characters of 101 males (a), 37 females (b), and six bioacoustic variables (c) of Pseudopaludicola mystacalis from 15 different localities in Brazil.

Maximum variation in temporal variables (notes per minute and number of pulses) of the calls of all specimens analyzed is 213.6 notes/min and 8 pulses/note. In the most distant known locations, the difference in the number of notes per minute and in the number of pulses is 100.3 notes $/ \mathrm{min}$ and 6 pulses/note, respectively. Considering subsets of populations from Brazilian Northeast and Brazilian Midwest, maximum interpopulational variation is 114.6 notes/min and 133.5 notes/min, respectively. There are 7 pulses/note in calls from populations of both areas. Maximum intrapopulational 


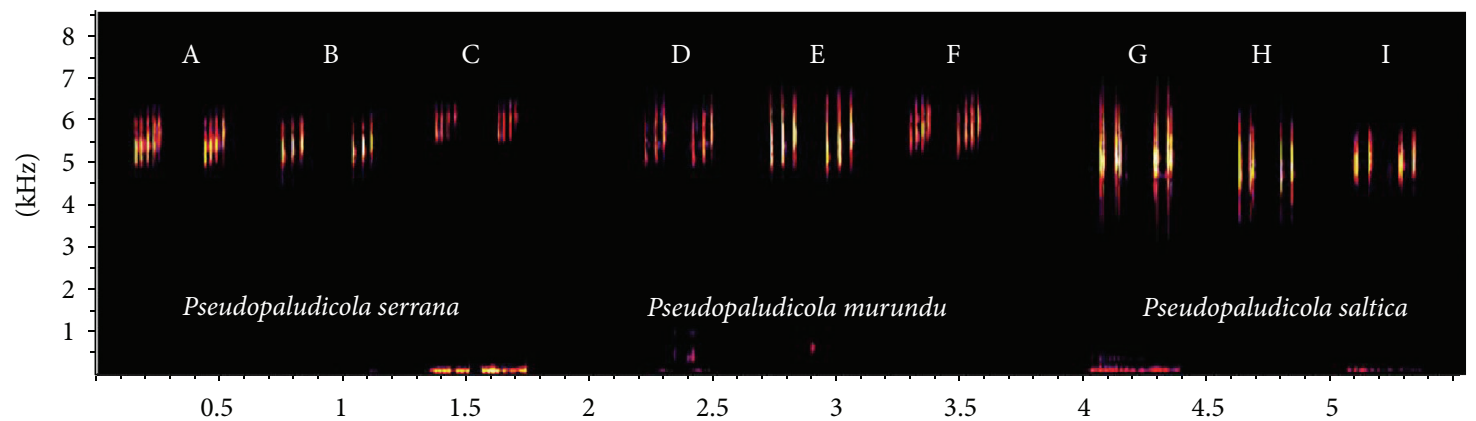

(s)

FIGURE 4: Spectrograms (DFT size $=512$ samples; two notes for each locality) of advertisement calls of Pseudopaludicola serrana (A-C) and P. murundu (D-F) recorded at their respective type-localities and P. saltica recorded in state of Minas Gerais-Uberlândia (G); state of Mato Grosso-Chapada dos Guimarães (type-locality; H) and Porto Estrela (I).

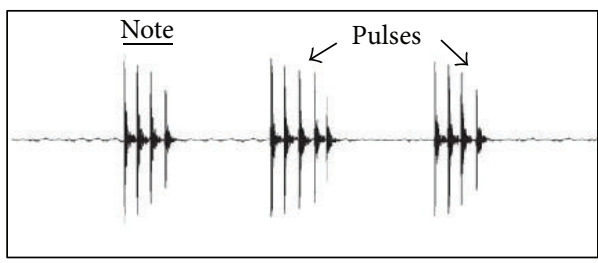

(a)

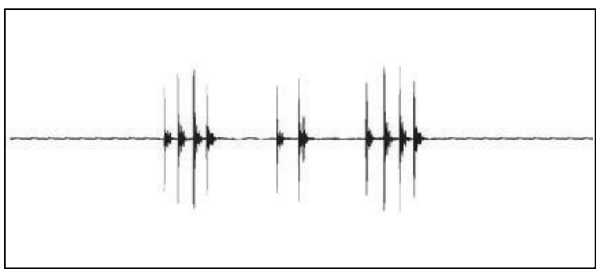

(c)

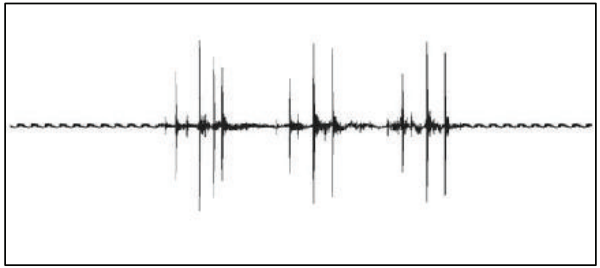

(e)

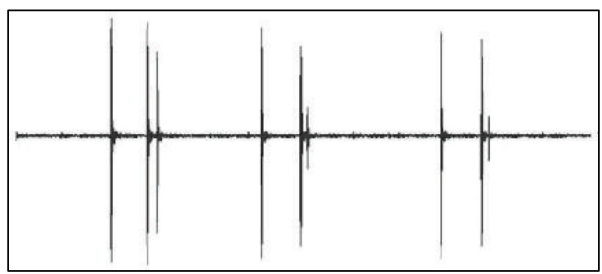

(g)

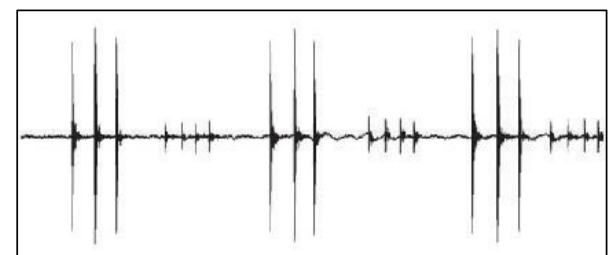

(b)

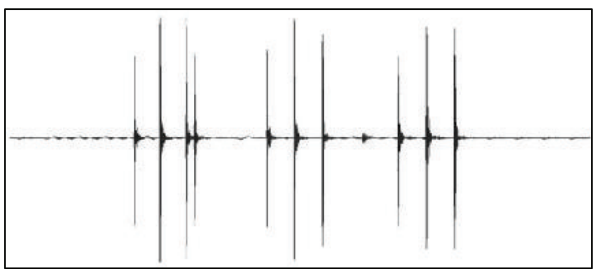

(d)

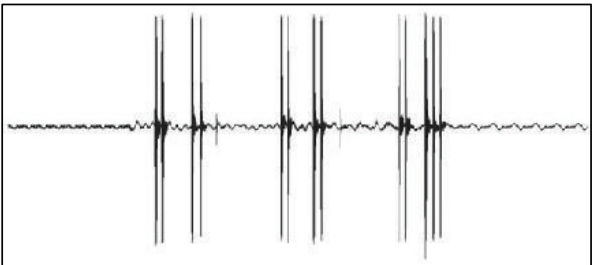

(f)

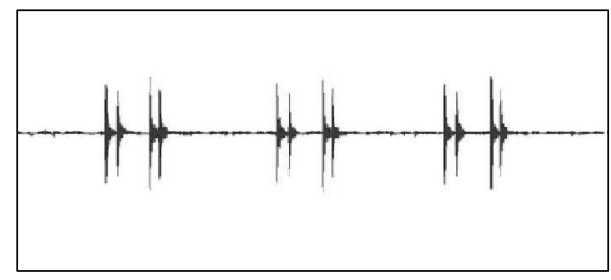

(h)

Figure 5: Oscillograms of advertisement calls of Pseudopaludicola serrana (a)-(b) and P. murundu (c)-(e) recorded at their respective typelocalities and P. saltica recorded in state of Minas Gerais: Uberlândia (f); state of Mato Grosso: Chapada dos Guimarães (type-locality (g)) and Porto Estrela (h). Total time of each oscillogram corresponds to $0.5 \mathrm{~s}$. 


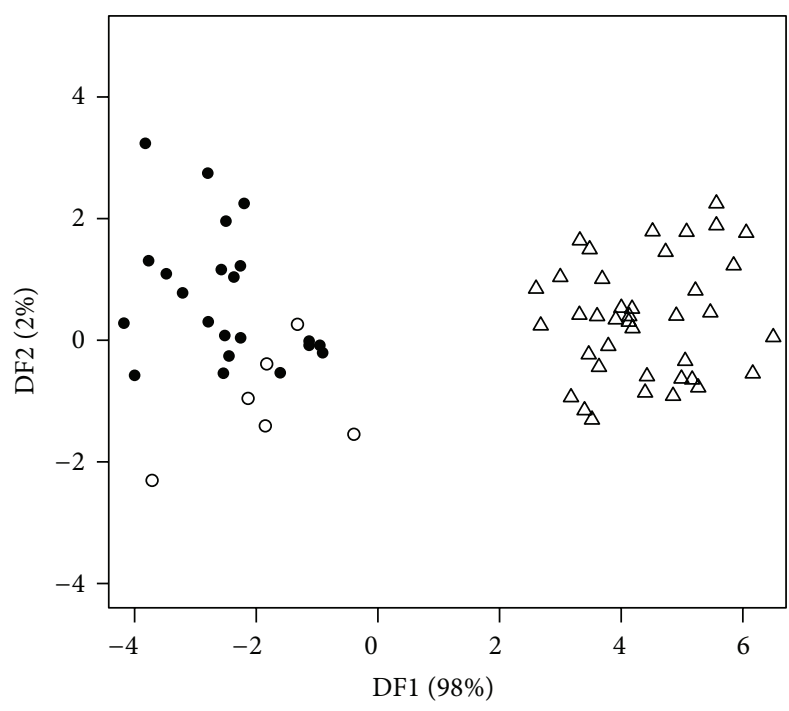

(a)

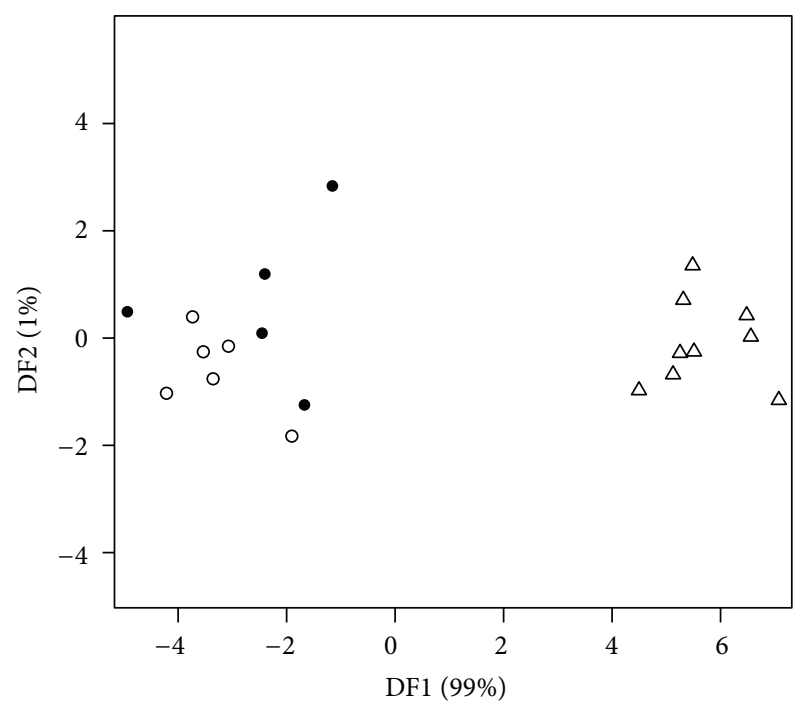

(b)

Figure 6: Scatterplots, on the two discriminant axes (DF1 and DF2), of scores of 12 morphometric characters of males (a) and six bioacoustic variables (b) of Pseudopaludicola murundu (open circles), P. saltica (triangles), and P. serrana (closed circles).

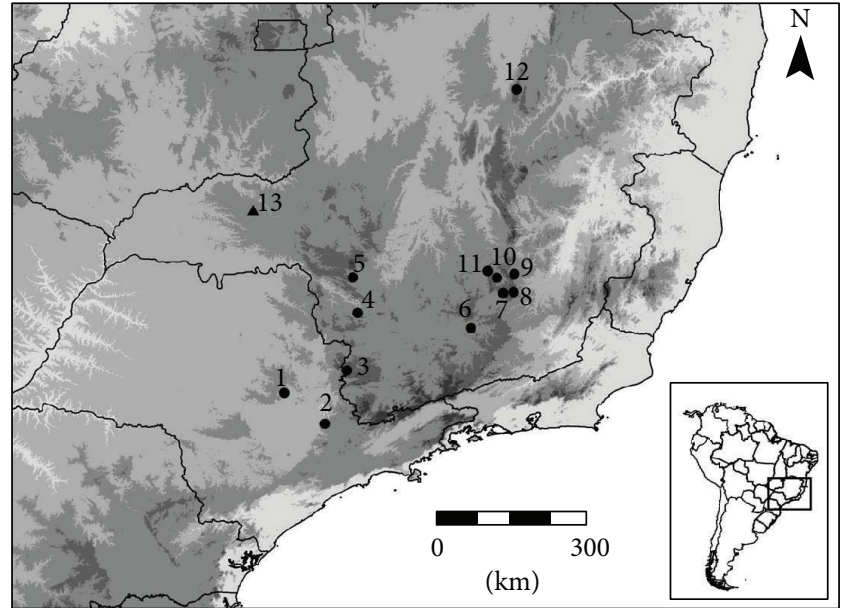

Elevation $(\mathrm{m})$

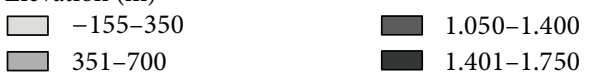

Figure 7: Geographical distribution of Pseudopaludicola murundu (circles) and P. saltica (triangles) in southeastern Brazil: state of São Paulo-Rio Claro (type locality (1)) and Campinas (2); state of Minas Gerais-Poços de Caldas (3), Alpinópolis (4) (see [17]), São Roque de Minas (5), São João Del Rei (6), Mariana (7), Ouro Branco (8), Itabirito (9), Brumadinho (10), Lavras Novas (11), Botumirim (12), and Uberlândia (13).

variation in the number of notes per minute and in the number of pulses in four localities from the state of Mato Grosso is 81 notes/min in Cuiabá and 5 pulses/note in Cuiabá and Nossa Senhora do Livramento (see Table 3 and [8]). Mean note duration does not differ significantly in all the examined calls (Table 3; $F=4.9 ; \mathrm{df}=2 ; P=0.03$ ).
TABLE 5: Summary of the number of male specimens correctly classified as Pseudopaludicola murundu, P. saltica, or P. serrana using discriminant function analysis of 12 morphometric measurements and seven bioacoustic variables.

\begin{tabular}{lccc}
\hline \multicolumn{4}{c}{ Morphometric measurements } \\
& P. murundu & $\begin{array}{c}\text { True group } \\
\text { P. saltica }\end{array}$ & P. serrana \\
\hline P. murundu & 1 & 0 & 5 \\
P. saltica & 0 & 39 & 0 \\
P. serrana & 3 & 0 & 19 \\
\hline Total number & 6 & 39 & 22 \\
$\%$ & 16 & 100 & 86 \\
\hline & Bioacoustic variables \\
& \multicolumn{4}{c}{ True group } \\
\hline P. murundu & P. murundu & P. saltica & P. serrana \\
P. saltica & 5 & 0 & 1 \\
P. serrana & 0 & 8 & 1 \\
\hline Total number & 3 & 0 & 2 \\
$\%$ & 6 & 9 & 5 \\
\hline
\end{tabular}

Acoustic analysis of geographical variation in species with an extent of occurrence of the magnitude seen in P. mystacalis sometimes reveals cryptic taxa being treated under a single name. However, this was not the case in $P$. mystacalis, a taxon that remained erroneously characterized and poorly recognized in the literature until recently [8]. Our results reveal a relatively small variation in morphological and acoustical traits of $P$. mystacalis and allow confirming the presence of the species in a wide geographical area along the Brazilian open ecosystems. 
TABle 6: Ratios of selected measurements (in $\mathrm{mm}$ ) of males of Pseudopaludicola murundu, $P$. saltica, and $P$. serrana. Values are presented as mean \pm standard deviation. $N=$ number of specimens analyzed.

\begin{tabular}{lccccccc}
\hline & HL/SVL & HW/SVL & HL/HW & HAL/SVL & FL/SVL & THL/SVL & TL/SVL \\
\hline P. serrana $(N=21)$ & $0.40 \pm 0.03$ & $0.36 \pm 0.02$ & $1.10 \pm 0.06$ & $0.27 \pm 0.02$ & $0.61 \pm 0.04$ & $0.56 \pm 0.03$ & $0.70 \pm 0.03$ \\
P. murundu $(N=5)$ & $0.39 \pm 0.04$ & $0.35 \pm 0.03$ & $1.11 \pm 0.09$ & $0.27 \pm 0.01$ & $0.66 \pm 0.02$ & $0.56 \pm 0.02$ & $0.70 \pm 0.03$ \\
P. saltica $(N=44)$ & $0.41 \pm 0.04$ & $0.38 \pm 0.03$ & $1.09 \pm 0.11$ & $0.26 \pm 0.03$ & $0.68 \pm 0.06$ & $0.55 \pm 0.05$ & $0.73 \pm 0.05$ \\
\hline
\end{tabular}

HAL: hand length; HL: head length; HW: head width; FL: foot length; SVL: snout-vent length; THL: thigh length; TL: tibia length.

4.2. Taxonomic Status of Pseudopaludicola serrana Toledo, 2010. When describing P. serrana, Toledo [15] used as morphological characteristics separating the three species belonging to the $P$. saltica group the aspect (relative size and coloration) of nuptial pads in the external part of finger I and aspect of the vocal sac. Such characteristics allow differing $P$. serrana and $P$. murundu from $P$. saltica but do not allow differing P. serrana from P. murundu [15]. Previously, Haddad and Cardoso [17] had called attention to the fact that nuptial pads were more developed in specimens of $P$. saltica from the type-locality (Chapada do Guimarães, Mato Grosso) than in specimens collected and recorded in localities in the states of Minas Gerais and São Paulo. In the same article, Haddad and Cardoso [17] also presented a spectrogram of the call of a specimen from Campinas, São Paulo. Based on such reported morphological evidence and acoustic parameters, we here argue that specimens from Minas Gerais and São Paulo attributed to P. saltica in Haddad and Cardoso [17] in fact correspond to $P$. murundu.

The only external morphological characteristic used by Toledo [15] to differ P. serrana from $P$. murundu was a shorter head length/head width ratio (HL/HW $=0.97 \pm 0.06$ in the five individuals of $P$. serrana evaluated; $1.11 \pm 0.07$ in 11 individuals of $P$. murundu). After having analyzed a higher number of specimens attributed to $P$. serrana $(N=21)$, we found that HL/HW (1.10 \pm 0.06 ; see Table 6) in this sample does not differ from the values presented in the original description, and confirmed herein, for P. murundu.

The description of $P$. serrana was also based on physical characteristics of its advertisement calls [15]. However, the original dataset is relatively low: 12 notes of a single male of $P$. saltica, 14 notes of 2 males of $P$. murundu, and 15 notes of 3 males of $P$. serrana were analyzed and compared. Only one out of four acoustic variables (pulse duration) was considered diagnostic for the new species. Toledo [15] also showed that dominant frequency range of $P$. serrana was completely nested within the dominant frequency range of $P$. murundu. However, when later proposing the synonymization of Pseudopaludicola riopiedadensis Mercadal de Barrio and Barrio, 1994 to Pseudopaludicola ternetzi MirandaRibeiro, 1937, Cardozo and Toledo [5] based their decision on "several important overlaps", including dominant frequency ranges, between the two species. Indeed, our data showed that dominant frequency contributed to higher loadings to separate species in the $P$. saltica group. Nonoverlapping dominant frequencies would therefore be expected between related but distinct species of Pseudopaludicola.
Bioacoustic data have proven to be useful for uncovering morphologically cryptic species in the genus Pseudopaludicola $[4-9,15,16]$. Advertisement calls of species in this genus might be divided into three distinct groups according to type of notes: nonpulsed notes, notes with concatenated pulses, and notes with nonconcatenated pulses [7]. Each group might be diagnosed by temporal (pulses per note, note and pulse duration, internotes and interpulses intervals, note rate, and pulse rate) and spectral variables (dominant frequency and harmonics), which in combination allow characterizing all the species for which calls were already analyzed, except for $P$. serrana and $P$. murundu. As evidenced by the recent synonymization of Pseudopaludicola riopiedadensis to P. ternetzi [15], and reinforced herein by the proposed synonymization of $P$. serrana to $P$. murundu, morphologically similar species of Pseudopaludicola presenting the same type of note and an overlap in their spectral acoustic variables are expected to represent the same taxon. Therefore, no arguments remain to consider $P$. serrana as a distinct species from $P$. murundu and the former must be considered as a junior synonym of $P$. murundu.

\section{Conclusions}

We here report on the variation in morphometric characters and variation in bioacoustic variables of the advertisement calls in fifteen Brazilian populations of Pseudopaludicola mystacalis. Although limited, our sample evidenced no statistical differences in any of the evaluated attributes and allowed us to confirm that this species is widely distributed in Brazil. Morphometric and bioacoustic data did not differ, also, in populations currently attributed to Pseudopaludicola serrana and Pseudopaludicola murundu, and the former taxon is here considered as a junior synonym of $P$. murundu. The data in the present work aims at contributing to a better understanding of the diversity and distribution patterns in the genus Pseudopaludicola.

\section{Appendices}

\section{A. Voucher Specimens Examined}

Pseudopaludicola murundu: Brazil. São Paulo: Rio Claro (type-locality; $22^{\circ} 19^{\prime} 52^{\prime \prime}$; $47^{\circ} 42^{\prime} 56^{\prime \prime} \mathrm{W}$ )-F: UFMT 18454; M: UFMT 18395-6; UFMT 18455-7.

Pseudopaludicola mystacalis: Brazil. Pará: Primavera $\left(00^{\circ} 57^{\prime} 22^{\prime \prime} \mathrm{S} ; 47^{\circ} 07^{\prime} 12^{\prime \prime} \mathrm{W}\right)$-M: UFMT 11651; UFMT 11827 ; 
UFMT 11833; UFMT 11836; UFMT 11839; Goiás: Uruaçu $\left(14^{\circ} 31^{\prime} 35^{\prime \prime} \mathrm{S}\right.$; $\left.49^{\circ} 07^{\prime} 54^{\prime \prime} \mathrm{W}\right)$-F: UFMT 18397-400; UFMT 18458-9; M: UFMT 18401-15; UFMT 18458-64; Mato Grosso: Barra do Garças $\left(15^{\circ} 31^{\prime} 57^{\prime \prime} \mathrm{S}\right.$; $\left.52^{\circ} 14^{\prime} 10^{\prime \prime} \mathrm{W}\right)-\mathrm{M}$ : UFMT 11097; UFMT 11307; UFMT 11319; UFMT 11324; Cáceres $\left(16^{\circ} 17^{\prime} 59^{\prime \prime} \mathrm{S}\right.$; $\left.58^{\circ} 09^{\prime} 09^{\prime \prime} \mathrm{W}\right)-\mathrm{F}$ : UFMT 5906; UFMT 5950; UFMT 5955; UFMT 5962; UFMT 9152; UFMT 10445; UFMT 10448; UFMT 13669; M: UFMT 10451-2; UFMT 10455; UFMT 10458; UFMT 10466; UFMT 10495; UFMT 10506; UFMT 10508; UFMT 13670; Chapada dos Guimarães (type-locality; $14^{\circ} 50^{\prime} 34^{\prime \prime} \mathrm{S} ; 55^{\circ} 23^{\prime} 10^{\prime \prime} \mathrm{W}$ )-F: UFMT 8109; M: UFMT 487; UFMT 817; UFMT 820; UFMT 12890; Cuiabá $\left(15^{\circ} 39^{\prime} 33^{\prime \prime} \mathrm{S} ; 55^{\circ} 56^{\prime} 30^{\prime \prime} \mathrm{W}\right)-\mathrm{M}$ : UFMT 15980; UFMT 2426; UFMT 2430; UFMT 2432; UFMT 2434-7; UFMT 2439; UFMT 7399; UFMT 7653; UFMT 8177-8; UFMT 8180; UFMT 8182; UFMT 8184-5; UFMT 13671; Nossa Senhora do Livramento $\left(16^{\circ} 21^{\prime} 58^{\prime \prime} \mathrm{S} ; 56^{\circ} 18^{\prime} 33^{\prime \prime} \mathrm{W}\right)$-F: UFMT 18465 ; UFMT 352; UFMT 6436; UFMT 6466-7; UFMT 6488; UFMT 6511; M: UFMT 4343; UFMT 6487; UFMT 6491; UFMT 6498; UFMT 6515; Poconé (16 $\left.30^{\prime} 58^{\prime \prime} \mathrm{S} ; 56^{\circ} 44^{\prime} 53^{\prime \prime} \mathrm{W}\right)$ M: UFMT 348-50; UFMT 889; UFMT 4316; UFMT 4318; UFMT 4321; UFMT 13672; and Porto Estrela $\left(15^{\circ} 35^{\prime} 05^{\prime \prime} \mathrm{S}\right.$; $\left.57^{\circ} 13^{\prime} 20^{\prime \prime} \mathrm{W}\right)-\mathrm{F}$ : UFMT 18466-7; UFMT 138; UFMT 13482; M: UFMT 18468-9; UFMT 402; UFMT 2200; UFMT 11346;

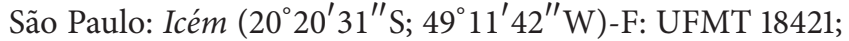
UFMT 18470-2; M: UFMT 18422-3; UFMT 18473 and Alto Alegre (21 $33^{\prime} 20^{\prime \prime} \mathrm{S}$; $\left.50^{\circ} 13^{\prime} 22^{\prime \prime} \mathrm{W}\right)$-F: UFMT 18474-5; UFMT 18479; M:UFMT 18476-8; UFMT 18480-6.

Pseudopaludicola saltica: Brazil. Mato Grosso: Chapada dos Guimarães (type-locality; $15^{\circ} 23^{\prime} 09^{\prime \prime} \mathrm{S}$; $55^{\circ} 50^{\prime} 24^{\prime \prime} \mathrm{W}$ )-M: UFMT 482; UFMT 819; UFMT 821; UFMT 823; UFMT 14335; UFMT 1437-41; UFMT 2873; UFMT 2877; UFMT 2880-1; F: UFMT 1442; Cuiabá: M: UFMT 270; UFMT 473; UFMT 476; UFMT 13657-68; F: UFMT 13655-6); Nova Lacerda (M: UFMT 13499-501); Porto Estrela: Estação Ecológica da Serra das Araras (M: UFMT 561), and Vila Bela da Santíssima Trindade (M: UFMT 4082; UFMT 4112; UFMT 4123; UFMT 4147; UFMT 4153; UFMT 4157; UFMT 4172). Mato Grosso do Sul: Sonora (M: UFMT 1147; UFMT 1195).

Pseudopaludicola serrana (junior synonym of $P$. murundu): Brazil. Minas Gerais: Brumadinho (typelocality; $20^{\circ} 06^{\prime} 32^{\prime \prime} \mathrm{S}$; $\left.43^{\circ} 58^{\prime} 53^{\prime \prime} \mathrm{W}\right)-\mathrm{F}$ : MCNAM 3675; M: UFMT 18424; UFMT 18451; MCNAM 3677-8; MCNAM 3680; Itabirito $\left(20^{\circ} 13^{\prime} 29^{\prime \prime} \mathrm{S}\right.$; $\left.43^{\circ} 48^{\prime} 49^{\prime \prime} \mathrm{W}\right)$-F: MCNAM 14620-1; M: MCNAM 14625; Lavras Novas $\left(20^{\circ} 28^{\prime} 57^{\prime \prime} \mathrm{S}\right.$; $\left.43^{\circ} 30^{\prime} 52^{\prime \prime} \mathrm{W}\right)-\mathrm{F}$ : MCNAM 3694; M: MCNAM 3695; MCNAM 3690; Mariana $\left(20^{\circ} 09^{\prime} 12^{\prime \prime} \mathrm{S} ; 43^{\circ} 30^{\prime} 02^{\prime \prime} \mathrm{W}\right)-\mathrm{F}$ : MCNAM 6465; M: MCNAM 6457; MCNAM 6461-2; Ouro Branco (20 $30^{\prime} 16^{\prime \prime} \mathrm{S}$; $\left.43^{\circ} 42^{\prime} 04^{\prime \prime} \mathrm{W}\right)-\mathrm{M}$ : MCNAM 6559; São João Del Rei (21 $08^{\prime} 25^{\prime \prime} \mathrm{S}$; $\left.44^{\circ} 17^{\prime} 31^{\prime \prime} \mathrm{W}\right)-\mathrm{M}$ : UFMT 18425-6; UFMT 18452-3 and Botumirim ( $\left.16^{\circ} 44^{\prime} 13^{\prime \prime} \mathrm{S} ; 42^{\circ} 34^{\prime} 29^{\prime \prime} \mathrm{W}\right)-\mathrm{F}$ : MCNAM 6713; M: MCNAM 6832; MCNAM 6834; MCNAM 6636; MCNAM 6642-3.

\section{B. Analyzed Sound Files}

Pseudopaludicola murundu: Brazil. São Paulo: Rio Claro (type-locality): LH 676, no voucher specimen; LH 677, call from UFMT 18455, LH 678, call from UFMT 18395 and FNJV 12976, no voucher specimen. Minas Gerais: São Roque de Minas ( $\left.20^{\circ} 13^{\prime} 20^{\prime \prime} \mathrm{S} ; 46^{\circ} 27^{\prime} 24^{\prime \prime} \mathrm{W}\right)$ : FNJV 4575, no voucher specimen; and Poços de Caldas (21 $\left.55^{\prime} 04^{\prime \prime} \mathrm{S} ; 46^{\circ} 34^{\prime} 02^{\prime \prime} \mathrm{W}\right)$ : FNJV 4576, no voucher specimen.

Pseudopaludicola mystacalis: Brazil. Ceará: Itapipoca $\left(03^{\circ} 24^{\prime} 58^{\prime \prime} \mathrm{S}\right.$; $\left.39^{\circ} 41^{\prime} 31^{\prime \prime} \mathrm{W}\right)$ : LH 655 , no voucher specimen; Taiba ( $\left.03^{\circ} 25^{\prime} 44^{\prime \prime} \mathrm{S} ; 38^{\circ} 57^{\prime} 43^{\prime \prime} \mathrm{W}\right)$ : LH 658, no voucher specimen; Goiás: Uruaçu: LH 639, call from UFMT 18410); Mato Grosso: Chapada dos Guimarães (type-locality): LH 13A-05, no voucher specimen); Cáceres: LH 47A-04, call from UFMT 10451; Cuiabá: LH 14A-01, call from UFMT 2426; LH 14A02, call from UFMT 2424; Poconé: LH 01A-01, call from UFMT 4321; and Nossa Senhora do Livramento: LH 04A10, call from UFMT 4330; Maranhão: Balsa $\left(07^{\circ} 28^{\prime} 49^{\prime \prime} \mathrm{S}\right.$; $\left.46^{\circ} 03^{\prime} 19^{\prime \prime} \mathrm{W}\right)$ : LH 284, no voucher specimen; Piauí: Brejo do Piauí (08 $11^{\prime} 50^{\prime \prime}$ S; $\left.42^{\circ} 49^{\prime} 59^{\prime \prime} \mathrm{W}\right)$ : LH 184, call from UFMT 11202; Pará: Primavera: LH 352, call from UFMT 11836; São Paulo: Icém: LH 701, call from UFMT 18423.

Pseudopaludicola saltica: Brazil. Mato Grosso: Cuiabá: LH 13A-01, call from UFMT 8187; Nova Lacerda: LH 42A-06, call from UFMT 13499; LH 42A-07, call from UFMT 13500; and Porto Estrela: LH 12, no voucher specimen; LH 13, call from UFMT 13678; LH 14, call from UFMT 16423; LH 16, call from UFMT 16417; LH 17, call from UFMT 16414 and LH 18, call from UFMT 16385. Minas Gerais: Uberlândia ( $18^{\circ} 58^{\prime} 30^{\prime \prime} \mathrm{S}$; $\left.48^{\circ} 17^{\prime} 26^{\prime \prime} \mathrm{W}\right)$ : LH 709, no voucher specimen.

Pseudopaludicola serrana (junior synonym of $P$. murundu): Brazil. Minas Gerais: Brumadinho: LH 673, call from UFMT 18451; LH 674, no voucher specimen; and São João Del Rei: LH 675, call from UFMT 18426 and FNJV 12879-80, no voucher specimen.

\section{Conflict of Interests}

The authors declare that there is no conflict of interests regarding the publication of this paper.

\section{Acknowledgments}

Special thanks go to Felipe Franco Curcio, Diva Maria Borges-Nojosa, and Luciana Barreto Nascimento for allowing access to the material under their care at "Coleção Zoológica de Vertebrados da Universidade Federal de Mato Grosso" (UFMT), “Coleção Herpetológica da Universidade Federal do Ceará" (UFC), and "Museu de Ciências Naturais" (MCNAM, Belo Horizonte, Minas Gerais), respectively; to Adão J. Cardoso (in memoriam) and Luis F. Toledo for the recordings and for allowing access, respectively, to bioacoustic samples deposited at "Fonoteca Neotropical Jacques Vielliard" (FNJV); to the CNPq project "Rede de pesquisa em anfíbios e répteis de ecossistemas não florestais brasileiros" (Process no. 563352/2010-8) for logistical support; to Vivian Uhlig (RAN/ICMBio) for estimates of extent of occurrence. André Pansonato thanks "Coordenação de Aperfeiçoamento de Pessoal de Nivel Superior” (CAPES) for a Ph.D. scholarship and Christine Strüssmann thanks CNPq for a research fellowship (Process no. 309541/2012-3). 


\section{References}

[1] K. D. Wells, The Ecology \& Behavior of Amphibians, The University of Chicago, Chicago, Ill, USA, 2007.

[2] M. Vences, M. Gehara, J. Köhler, and F. Glaw, "Description of a new Malagasy treefrog (Boophis) occurring syntopically with its sister species, and a plea for studies on non-allopatric spéciation in tropical amphibians," Amphibia Reptilia, vol. 33, no. 3-4, pp. 503-520, 2012.

[3] I. De La Riva, R. Márquez, and J. Bosch, "Description of the advertisement calls of some South American Hylidae (Amphibia, Anura): taxonomic and methodological consequences," Bonner Zoologische Beiträge, vol. 47, pp. 175-185, 1997.

[4] F. S. de Andrade and T. R. de Carvalho, "A new species of Pseudopaludicola Miranda-Ribeiro (Leiuperinae: Leptodactylidae: Anura) from the Cerrado of southeastern Brazil," Zootaxa, vol. 3608, no. 5, pp. 389-397, 2013.

[5] D. Cardozo and L. F. Toledo, "Taxonomic status of Pseudopaludicola riopiedadensis Mercadal de Barrio and Barrio, 1994 (Anura, Leptodactylidae, Leiuperinae)," Zootaxa, vol. 3734, pp. 571-582, 2013.

[6] T. R. de Carvalho, "A new species of Pseudopaludicola MirandaRibeiro (Leiuperinae: Leptodactylidae: Anura) from the Cerrado of southeastern Brazil with a distinctive advertisement call pattern," Zootaxa, no. 3328, pp. 47-54, 2012.

[7] F. M. Magalhães, D. Loebmann, M. N. C. Kokubum, C. F. B. Haddad, and A. A. Garda, "A new species of Pseudopaludicola (Anura: Leptodactylidae: Leiuperinae) from Northeastern Brazil," Herpetologica, vol. 70, pp. 77-88, 2014.

[8] A. Pansonato, C. Strüssmann, J. R. Mudrek, and I. A. Martins, "Morphometric and bioacoustic data on three species of Pseudopaludicola Miranda-Ribeiro, 1926 (Anura: Leptodactylidae: Leiuperinae) described from Chapada dos Guimarães, Mato Grosso, Brazil, with the revalidation of Pseudopaludicola ameghini (Cope, 1887)," Zootaxa, vol. 3620, no. 1, pp. 147-162, 2013.

[9] I. J. Roberto, D. Cardozo, and R. W. Ávila, "A new species of Pseudopaludicola (Anura, Leiuperidae) from Western Piauí State, Northeast Brazil," Zootaxa, vol. 3636, no. 2, pp. 348-360, 2013.

[10] S. B. Barreto, M. S. Tinoco, D. Couto-Ferreira, and H. C. Browne-Ribeiro, "Distribuição de Pseudopaludicola aff. falcipes (Anura; Leiuperidae) na restinga do litoral norte da Bahia, Brasil," Revista Latino-Americana de Conservação, vol. 2, pp. 2736, 2012.

[11] E. R. Fávero, A. C. P. Veiga-Menoncello, D. C. Rossa-Feres et al., "Intrageneric karyotypic variation in Pseudopaludicola (Anura: Leiuperidae) and its taxonomic relatedness," Zoological Studies, vol. 50, no. 6, pp. 826-836, 2011.

[12] M. Jansen, R. Bloch, A. Schulze, and M. Pfenninger, "Integrative inventory of Bolivia’s lowland anurans reveals hidden diversity," Zoologica Scripta, vol. 40, no. 6, pp. 567-583, 2011.

[13] C. P. D. Prado, M. Uetanabaro, and C. F. B. Haddad, "Breeding activity patterns, reproductive modes, and habitat use by anurans (Amphibia) in a seasonal environment in the Pantanal, Brazil," Amphibia Reptilia, vol. 26, no. 2, pp. 211-221, 2005.

[14] R. A. Silva, I. A. Martins, and D. C. Rossa-Feres, "Bioacústica e sítio de vocalização em taxocenoses de anfíbios de área aberta no Noroeste Paulista," Biota Neotropica, vol. 8, pp. 123-134, 2008.
[15] L. F. Toledo, "Description of a new species of Pseudopaludicola Miranda-Ribeiro, 1926 from the state of São Paulo, Southeastern Brazil (Anura, Leiuperidae)," Zootaxa, no. 2681, pp. 47-56, 2010.

[16] L. F. Toledo, S. Siqueira, T. C. Duarte, A. C. P. Veiga-Menoncello, S. M. Recco-Pimentel, and C. F. B. Haddad, "Description of a new species of Pseudopaludicola Miranda-Ribeiro, 1926 from the state of São Paulo, Southeastern Brazil (Anura, Leiuperidae)," Zootaxa, no. 2496, pp. 38-48, 2010.

[17] C. F. B. Haddad and A. J. Cardoso, "Taxonomia de três espécies de Pseudopaludicola (Anura, Leptodactylidae)," Papéis Avulsos de Zoologia, vol. 36, pp. 287-300, 1987.

[18] T. C. Duarte, A. C. P. Veiga-Menoncello, J. F. R. Lima et al., "Chromosome analysis in Pseudopaludicola (Anura, Leiuperidae), with description of sex chromosomes XX/XY in P. saltica," Hereditas, vol. 147, no. 2, pp. 43-52, 2010.

[19] A. C. P. Veiga-Menoncello, L. B. Lourenço, C. Strüssmann et al., "A phylogenetic analysis of Pseudopaludicola (Anura) providing evidence of progressive chromosome reduction," Zoologica Scripta, vol. 43, no. 3, pp. 261-272, 2014.

[20] W. R. Heyer, A. S. Rand, C. A. G. Cruz, O. L. Peixoto, and C. E. Nelson, "Frogs of Boracéia," Arquivos de Zoologia, vol. 31, pp. 231-410, 1990.

[21] W. E. Duellman, The Hylid Frogs of Middle America, vol. 1 of Monograph of the Museum of Natural History of University of Kansas, 1970.

[22] R Development Core Team, The R Project for Statistical Computing, Vienna, Austria, 2013, http://www.r-project.org.

[23] P. E. Vanzolini, "Ecological and geographical distribution of lizards in Pernambuco, Northeastern Brasil (Sauria)," Papéis Avulsos de Zoologia, vol. 18, no. 4, pp. 61-90, 1974.

[24] J. M. Cei, "Amphibians of Argentina.," Monitore Zoologico Italiano, Nuova Serie Monografia, vol. 2, pp. 1-609, 1980.

[25] F. Brusquetti and E. O. Lavilla, "Lista comentada de los anfibios de Paraguay," Cuadernos de Herpetología, vol. 20, no. 2, pp. 3-79, 2006.

[26] I. De La Riva, J. Köhler, S. Lötters, and S. Reichle, “Ten years of research on Bolivian amphibians: updated checklist, distribution, taxonomic problems, literature and iconography," Revista Española Herpetologica, vol. 14, pp. 19-164, 2000. 

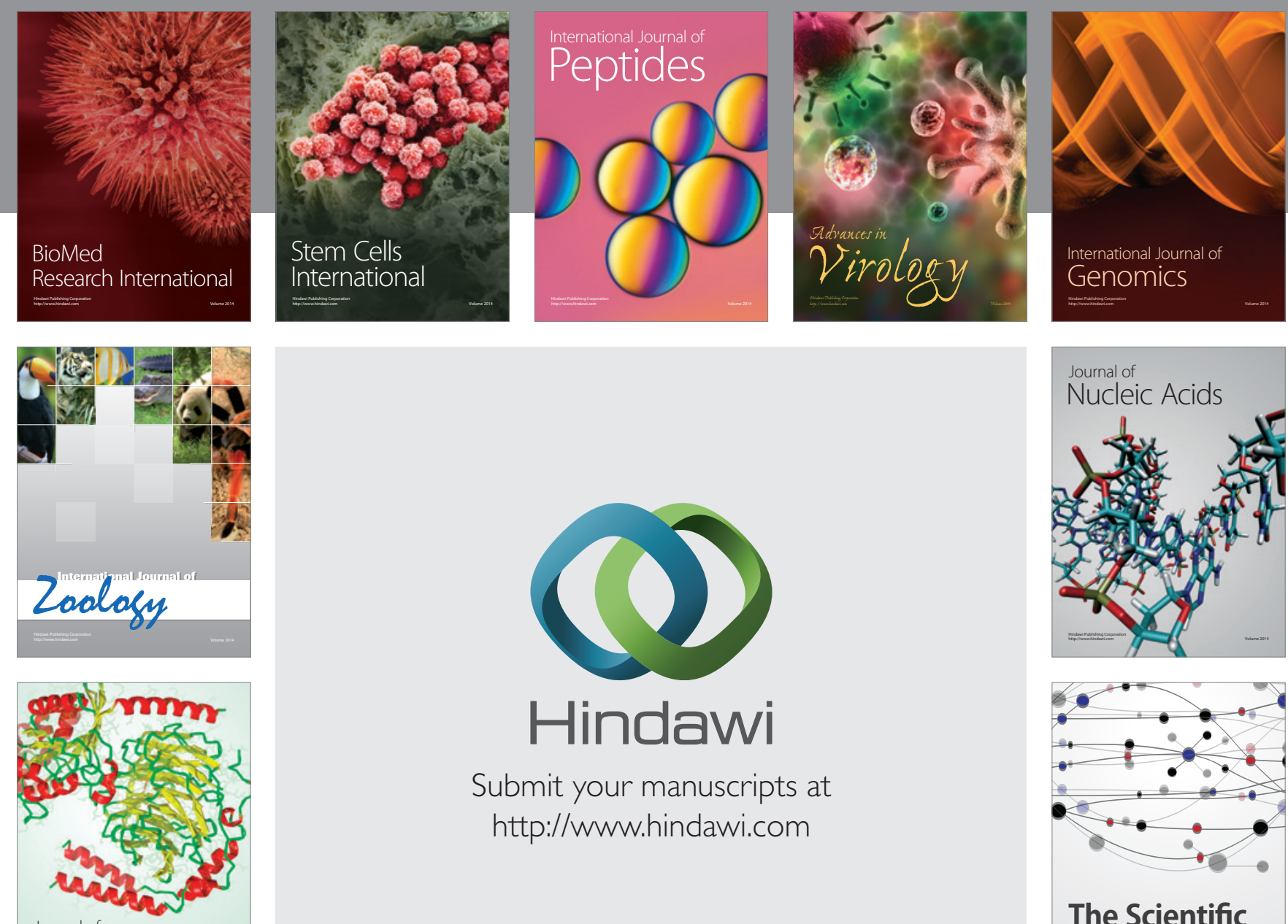

Submit your manuscripts at

http://www.hindawi.com

Journal of
Signal Transduction
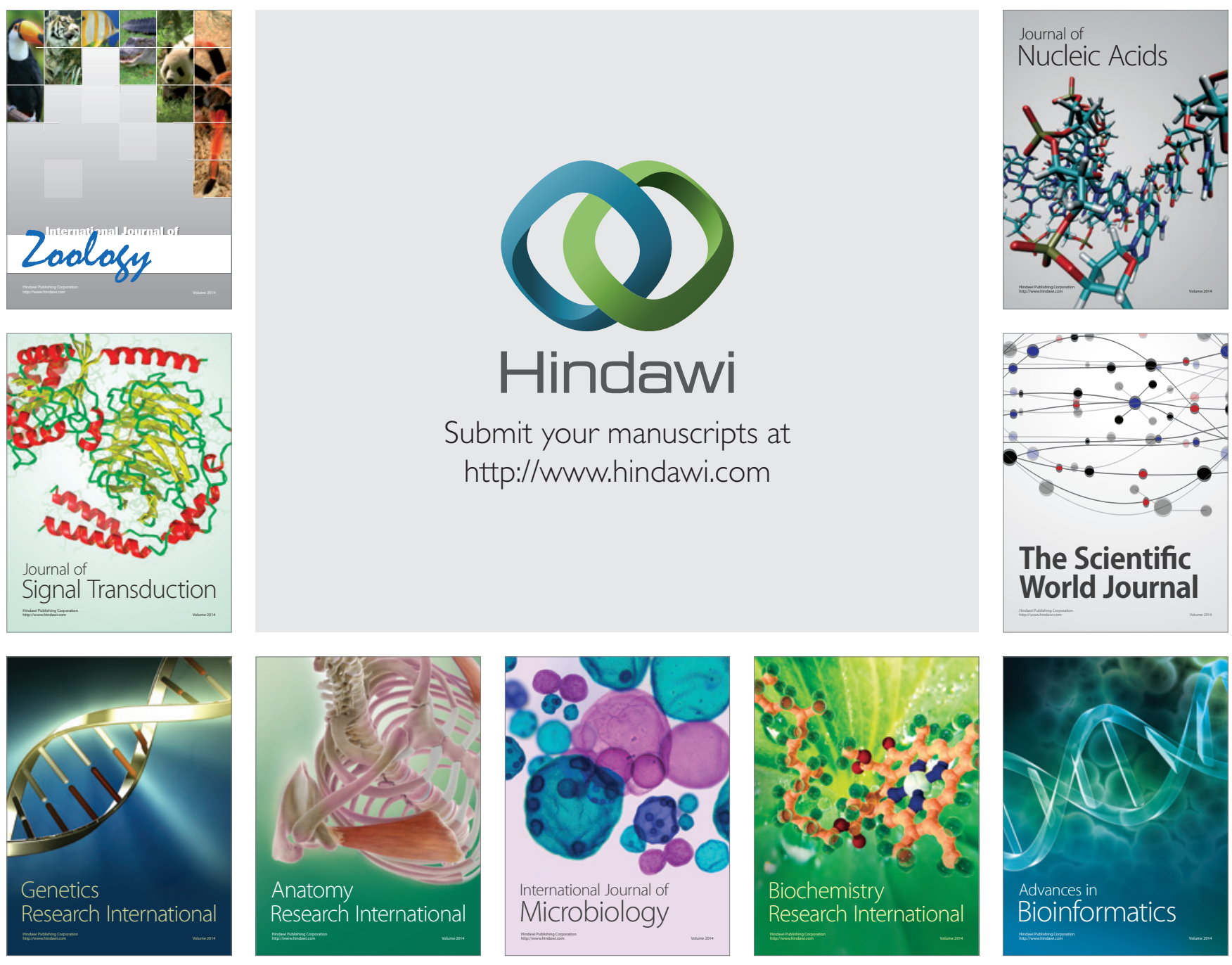

The Scientific World Journal
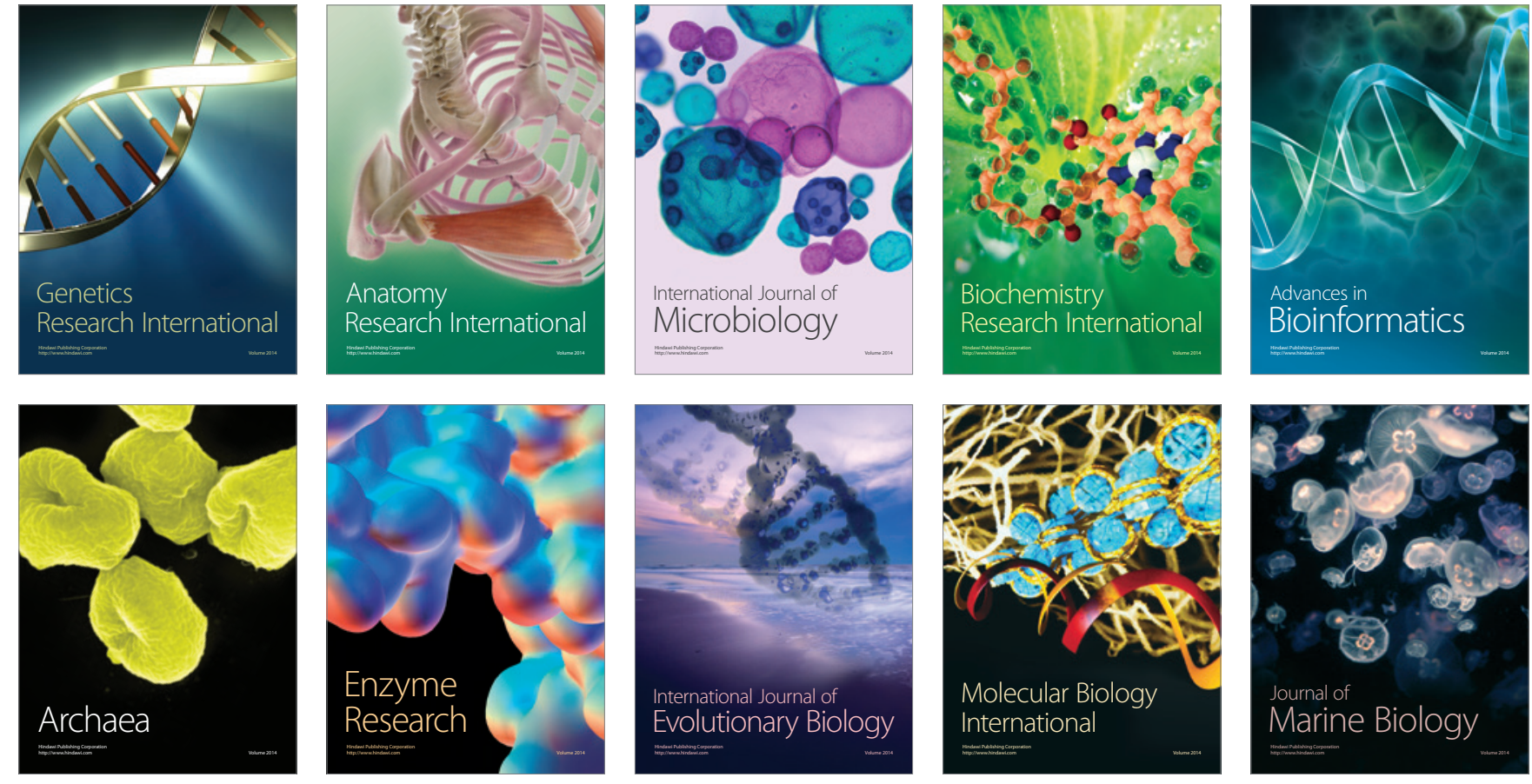